\title{
İkinci El Çevrimiçi Pazarlarda İlgilenim, Yenilikçilik ve Algılanan Riskin Tüketicilerin Satın Alma Tarzına Etkisi* \\ (The Effect of Involvement, Innovativeness and Perceived Risk on Consumers Purchasing Style in Second Hand Online Markets)
}

\author{
Didem GEZMIŞOĞLU ŞEN (iD a Gonca TELLI id b \\ a Maltepe Üniversitesi, Lisansüstü Eğitim Enstitüsü, İşletme Bölümü, İstanbul, Türkiye. didemgezmisoglu84@hotmail.com.tr \\ b Doğuş Üniversitesi, İktisadi ve İdari Bilimler Fakültesi, İşletme (İngilizce) Bölümü, İstanbul, Türkiye. gtelli@dogus.edu.tr
}

\begin{tabular}{l} 
MAKALE BİLGİsi \\
\hline Anahtar Kelimeler: \\
İkinci El Çevrimiçi alışveriş \\
İkinci El Çevrimiçi Lüks \\
Ürün \\
Yenilikçilik \\
İlgilenim \\
Algilanan Risk
\end{tabular}

Gönderilme Tarihi: 27 Haziran 2021

Revizyon Tarihi: 8 Eylül 2021 Kabul Tarihi: 15 Eylül 2021

Makale Kategorisi: Araştırma Makalesi

\section{ÖZET}

Amaç - Dijitalleşme ile başlayan tüketicilerin yaşam tarzlarındaki değişimler tüketicileri çevrimiçi alışverişe yönlendirmiştir. Çevrimiçi alışverişin tüketiciler tarafından yaygın bir şekilde kullanılmasıyla birlikte ikinci el alışverişin çevrimiçi platformlarda önemli bir seçenek haline geldiği görülmektedir. Bu doğrultuda çalışmada, çevrimiçi ikinci el pazarlarda yenilikçilik, algılanan risk, ilgilenim, ikinci el satın alma motivasyonları ve ikinci el satın alma niyeti ile satın alma tarzları arasındaki ilişkiler araştırılmıştır.

Yöntem - Araştırma çevrimiçi alışveriş yapan tüketiciler üzerinde gerçekleştirilmiştir. Araştırmada kolayda örnekleme yöntemi kullanılmıştır. Veriler, çevrimiçi anket yöntemiyle toplanmıştır. Veri toplama süreci sonunda eksik/hatalı dolduran kişiler çıkarılmış olup 689 adet anket ile çözümlemeye geçilmiştir. Çözümlemeler IBM SPSS 22 paket programı kullanılarak analiz edilmiştir.

Bulgular - Yapılan analizlerden elde edilen bulgulara göre, hedonik satın alma ile ilgilenim, yenilikçilik, algılanan risk, ikinci el sosyal motivasyon ve ikinci el lüks motivasyonu arasında pozitif ilişkiler olduğu sonucuna ulaşılmıştır. Kompulsif satın alma ile ilgilenim, yenilikçilik, ikinci el sosyal motivasyon ve ikinci el lüks motivasyonu arasında da pozitif ilişkiler olduğu sonuçlarına ulaşılmıştır.

Tartışma - İkinci el konusunda hizmet veren alışveriş siteleri çevrimiçi ortamda gelişen yeni pazar dinamikleri ile ortaya çıkan yapılardır. Bu yüzden bu tarz alışverişlerle ilgili satın alma davranışlarının yenilikçilik, algılanan risk, ilgilenim, ikinci el satın alma motivasyonları ve ikinci el satın alma niyeti gibi tüketici davranışlarının anlaşılması hem e-ticaret hem de alışveriş yapan tüketicilerin özelliklerinin bilinmesi açısından detaylandırılmaktadır.

\begin{tabular}{|c|c|}
\hline ARTICLE INFO & ABSTRACT \\
\hline $\begin{array}{l}\text { Keywords: } \\
\text { Second-hand online } \\
\text { shopping } \\
\text { Second-hand online luxury } \\
\text { product }\end{array}$ & $\begin{array}{l}\text { Purpose- Changes in the lifestyles of consumers starting with digitalization have led consumers to shop } \\
\text { online. With the widespread use of online shopping by consumers, second-hand shopping appears to have } \\
\text { become an important option on online platforms. Accordingly, the study investigated the relationships } \\
\text { between innovativeness, perceived risk, involment, motivations for second-hand purchasing and second- } \\
\text { hand purchasing intentions and purchasing styles in online second-hand markets. }\end{array}$ \\
\hline $\begin{array}{l}\text { Innovativeness, } \\
\text { Involvement } \\
\text { Perceived risk }\end{array}$ & $\begin{array}{l}\text { Design/methodology/approach- The research was carried out on consumers who shop online. Snowball } \\
\text { sampling method was used in the research. The data was collected through online surveying. At the end of } \\
\text { the data collection process, people who filled in incomplete/incorrectly were removed and } 689 \\
\text { questionnaires were started to analyze. IBM SPSS } 22 \text { package program were used for the analyses. }\end{array}$ \\
\hline Received 27 June 2021 & 1 \\
\hline Revised 8 September 2021 & positive relationships between interest in hedonic purchasing, involvement, perceived risk, second-hand \\
\hline $\begin{array}{l}\text { Accepted } 15 \text { September } \\
2021\end{array}$ & $\begin{array}{l}\text { social motivation and second-hand luxury motivation. It has been concluded that there are also positive } \\
\text { relationships between compulsive purchasing, involvement, second-hand social motivation and second- } \\
\text { hand luxury motivation. }\end{array}$ \\
\hline $\begin{array}{l}\text { Article Classification: } \\
\text { Research Article }\end{array}$ & $\begin{array}{l}\text { Discussion- Second-hand shopping sites are the structures that emerge with new market dynamics } \\
\text { developing online. Therefore, the understanding of consumer behaviors such as innovativeness, perceived } \\
\text { risk, involvement, second-hand purchasing motivations and second-hand purchasing intentions of } \\
\text { purchasing in relation to such purchases is detailed in terms of knowing the characteristics of both e- } \\
\text { commerce and shoppers. }\end{array}$ \\
\hline
\end{tabular}

*Bu çalışma, Prof. Dr. Gonca TELLİ danışmanlığında Didem GEZMișOĞLU ŞEN'in Maltepe Üniversitesi Lisansüstü Eğitim Enstitüsü, İşletme ana bilim dalı Doktora programında hazırlanan “İkinci El Çevrimiçi Pazarlarda İlgilenim, Yenilikçilik ve Algılanan Riskin Tüketicilerin Satın Alma Tarzına Etkisi" adlı doktora tez çalışmasından üretilmiştir. 


\section{Giriş}

Çevrimiçi alışveriş son yıllarda tüketiciler arasında popüler hale gelmiştir. Hatta Covid-19 sonrasında bu tarz alışveriş çoğu zaman yüz yüze alışverişten daha fazla tercih edilir bir alışveriş tarzına dönüşmüştür. Eticaretin yoğun olarak kullanılmaya başlaması ile bireylerin de bu ortamda kişiden kişiye bireysel satış yapmaları olanaklı hale gelmiştir. Bu durum çevrimiçi ikinci el alışverişin popülaritesini artırmıştır. İkinci el alışveriş konusunda hizmet veren alışveriş siteleri çevrimiçi ortamda gelişen bu yeni pazar dinamikleri ile oluşmaktadır. Pazarda ve tüketici davranışlarındaki değişimler çevrimiçi ikinci el pazarı etkilemektedir. Çevrimiçi ikinci el pazarın büyümesi ile e-ticaret yapan işletmelere yeni iş imkânları doğmaktadır.

Çevrimiçi ikinci el alışveriş tıpkı birinci elde olduğu gibi satıcı ile alıcı arasında etkileşimin olduğu, tüketici istek ve ihtiyaçlarının hızlı bir şekilde karşılandığı, ürün ve ödeme güvencesi olan genelde ana üretici yerine bir başka kurum ya da kişi tarafından sağlanan bir alışveriş yapısıdır. Burada ürünün yeni ve eski olmasından ziyade ikinci elden ve çoğu zaman piyasa satış fiyatının altında ve C2C denilen ticari modelle müşteriden müşteriye satışının yapılabilmesidir. Bu yüzden ikinci el çevrimiçi pazar sisteminin maliyet ve aranan ürünün bulunması bakımından pazardaki ve tüketici gözündeki yeri ayrıdır.

Güvenlik, ödeme ve teslimat konularında her geçen gün iyileştirmeler yaparak sorunların en aza indirgenmesiyle beraber çevrimiçi alışveriş yapan tüketicilerin sayısı artmaktadır. Çevrimiçi tüketicilerin sayısının artmasına paralel olarak ikinci el alışveriş yapan tüketicilerin sayısının da arttığ görülmektedir. TÜİK Hanehalkı Bilişim Teknolojileri Kullanım Araştırmasına göre 2020 yılında \%60,9 ile giyim, ayakkabı ve aksesuar en çok çevrimiçi alışveriş yapılan alanlar olmuştur. Öte yandan çevrimiçi Pazar gelişirken çevrimiçi ikinci el pazarda da büyük ilerlemeler olmaktadır.

Dünyada çevrimiçi ikinci el alışveriş 2012 yılında 11 milyar dolar, 2019 yılında 22 milyar dolar, 2020 yılında 33,03 milyar dolar seviyelerindedir ve 2024 yılında ise 64 milyar dolar olacağ (Shahbandeh, 2021). Bu pazarda 2018'den 2023'e kadar beş kat büyüme beklenmektedir. İkinci el pazar ürün çeşitliliği ve ürün özellikleri itibariyle tüm ürünleri kapsar hale dönüşmektedir. Örneğin eski bir ev alımından, bebek sandalyesi alımına kadar pek çok ürün bu pazarda yerini almaktadır. Kolayda beğenmeli ve özellikli ürün sınıfları bütün bu yapıda yerini almaktadır (Kavak \& Sığındı, 2012). Ayrıca çevrimiçi lüks ürün satın alan tüketicilerinin \%26'sının ikinci el lüks ürün satın aldığı saptanmıştır. Boston Consulting Group'un 2019 yılında yaptığı araştırmaya göre lüks ürün kullanan kişilerin $1 / 3^{\prime}$ ü satın aldıklarını lüks ürünleri yeniden sattıkları bilinmektedir. Bu da çevrimiçi ikinci el pazarda en az 2/3'lük bir satış potansiyeli ortaya çıkarmaktadır. İkinci el lüks ürün pazarında ise 2022 yılına kadar \%12 büyüme beklenirken 1. el lüks ürün pazarında ise ancak \%3 büyüme beklenmektedir (Boston Consulting Group, 2019).

Dünyada da bu tarz alışveriş giderek yaygınlaşmaktadır. 2016 yılında İtalya'da internetin ikinci el ekonominin yaygınlaşmasına etkisi üzerine yapılan araştırmada tüketicilerin \%68'i internetin ikinci el ürünlere daha erişilebilir olmasını sağladığını, \%58'inininternetin ikinci elde aradığını bulmayı kolaylaştırdığını ve \%50'sinin ise tasarruf etmeye katkı sağladığını düşünmektedirler (Statista; 2016a). Amerika'da Haziran 2017 yılında yapılan diğer bir araştırmada çevrimiçi ikinci el alışveriş yapan tüketicilerin \%65'i çevrimiçi alışveriş platformlarından alışveriş yaptıklarını, \%30'u ise Facebook sayfalarını kullandıklarını söylemişlerdir. Kalan \%27 ise garantili kullanılmış ürün satan profesyonel satıcılardan satın aldıklarını belirtmişlerdir (Statista; 2019a). Güney Kore'de 2020 yılında yapılan araştırmada akıllı telefonlarına ikinci el alışveriş sitesi uygulamalarını indirip indirilmediği sorulmuştur. Tüketicilerin \%73,1'i uygulama kullanmadığını, \%26,9'u ise uygulamaları indirdiğini söylemişlerdir (Statista; 2020a). 2020 yılında Çin de yapılan bir araştırmada 20152019 yılları arasında çevrimiçi ikinci el perakendenin brüt ürün değerine bakılmıştır. 2015 yılında 4,59 milyar $¥$ (Çin Yuanı), 2019 yılında 259,69 milyar ¥ ve 2020 yılına bakıldığında 374,55 milyar ¥ olduğu görülmektedir (Statista; 2020b).

Pazar bu kadar büyük ve gelişmeye açıkken dijital pazarlamada ikinci el alışveriş siteleri ile ilgili olarak literatürde 2020 yılına kadar çevrimiçi tüketicilerin çevrimiçi ortamda yer alan çevrimiçi ikinci el pazara eğilimleri hakkında fazla bir akademik çalışmaya rastlanılmamıştır. Bu yüzden ikinci el alışverişi irdelemek yeni pazarın ve giderek çevrimiçi alışveriş yapan kişilerin özelliklerinin anlaşılması ve bu alanda yeni modellere yol gösterme açısından önemlidir.

Bunun yanında Türkiye'de ise 30 binden fazla çevrimiçi alışveriş sitesinin ödeme altyapısını sağlayan İyzico 
firması 2019 yılına ait ikinci el çevrimiçi alışveriş verilerine göre (www.iyzico.com);

- İkinci el alışveriş sitelerindeki tüketici profilleri incelendiğinde \%70 oranında kadın kullanıcılardan oluşmaktadır.

- İkinci el alışveriş sitelerindeki erkek kullanıcılar ise yalnızca \%9'dur.

- Çevrimiçi ikinci el alışverişin en çok yapıldığı şehir \%30 ile İstanbul'dur.

- Çevrimiçi ikinci el alışverişin en düşük olduğu il ise \%1,03 ile Sakarya'dır.

- Çevrimiçi ikinci el alışverişte en çok satılan ürün \%12 ile ayakkabılardır.

- Çevrimiçi ikinci el alışverişte en az satılan ürün \%1,32 ile ceketlerdir.

- Çevrimiçi ikinci el alışverişte sepet tutarının en yüksek olduğu ürün ise 87,09 TL ile çantalardır.

Bu çalışma ile çevrimiçi ikinci el pazarlardaki tüketicilerin yenilikçilik, algılanan risk, ilgilenim, ikinci el satın alma niyeti ve ikinci el satın alma motivasyonlarının, tüketicilerin satın alma tarzlarına olan etkisi incelenmektedir. Bu pazarda tüketiciyi ikinci el ürün satın almaya yönlendiren ve motive eden konuların neler olduğuna ilişkin olarak tespitlerde bulunulmaya çalışılmıştır. Böylece ikinci el çevrimiçi pazarda alışveriş yapan tüketicilerin değişen davranışları incelenerek, ikinci el alışveriş literatürüne katkıda bulunmak amaçlanmaktadır.

\section{Literatür Araştırması}

\section{1. İkinci El Çevrimiçi Pazar ve Alışveriş}

Çevrimiçi alışverişin popüler hale gelmesiyle birlikte özellikle de dünyada çevrimiçi alışveriş çok hızlı bir şekilde büyümektedir (Fernando vd., 2018). Çevrimiçi alışveriş kültürünün değişmesi, tüketici davranışlarında değişikliklere yol açmıştır. İşletmeler, eskiden sadece diğer işletmeler ile rekabet ederken ikinci el pazarların ortaya çıkmasıyla artık tüketicileriyle de rekabet eder hale gelmiştir. 2010 yılında Guiot ve Roux alternatif tüketim kanallarına artan ilgi ile geleneksel perakendeciliğe yönelik eleştirilerin ışığında sekiz faktörlü ikinci el alışveriş motivasyonları ölçeği önermiştir. Ayrıca ikinci el alışveriş yapan tüketiciler için üç farklı motivasyon belirlenmiştir. Bunlar; kritik motivasyon, ekonomik motivasyon, hedonik motivasyonudur. Guiot ve Roux (2010) tarafından geliştirilen orijinal İETMÖ (İkinci El Tüketim Motivasyonu Ölçeği) 3 faktörlü bir yapıya sahiptir. Guiot ve Roux tarafından yapılan çalı̧̧mayı temel alarak Steffen 2016'da Alman tüketicilerin ikinci el alışveriş alışkanlıkları hakkında çalışmıştır. Elde edilen bulgulara göre; Alman tüketicilerin sosyal motivasyonunun ve nostaljik motivasyonunun daha fazla olduğu gözlemlenmiştir. Ayrıca, yaşam tarzının da ikinci el satın alma kararlarında önemli bir rol oynadığı görülmüştür. Ferraro, Sands, Govan (2016) ise tüketicinin ikinci el alışveriş davranışını ve modaya uygunluğunu içeren motivasyonlarının neler olduğunu incelemiştir. Bu çalışmanın sonucunda kritik motivasyon, ekonomik motivasyon, rekreasyonel motivasyon ve dördüncüsü moda motivasyonunun insan davranışını etkilediği anlaşılmıştır. Turunen ve arkadaşları (2019) tarafından yapılan araştırmada satış sürecindeki lüks ürünlerin anlam ve değerleri incelemektedir. Lüks ürünlerin tüketimi, tüketicilerin aktif olarak yeni roller benimsediği farklı durumlar söz konusu olmaktadır. Padmavathy ve arkadaşları (2019) tarafından yapılan çalışmada çevrimiçi ikinci el alışverişin ve $\mathrm{C} 2 \mathrm{C}$ (müşteriden müşteriye) e-ticaretin giderek popülaritesinin artması ve pazarın büyümesine ilişkin olarak çevrimiçi ikinci el alışveriş motivasyonu ölçeği geliştirilmiştir. Kessous ve Florence (2019) ise tüketicilerin sahip oldukları/olmadıkları lüks ürünler ile kurdukları ilişkileri belirlemek için birbirini takip eden ikinci el ve birinci el lüks ürünlerin satın alınma şeklinin duygusal ve bilişsel temsillerine odaklanan iki çalışma gerçekleştirmiştir. Abbes, Hallem, Taga (2020) markalar için iş birliğine dayalı yeniden dağıtım platformlarının risklerini belirleyerek, onların içsel ve dışsal özelliklerinin davranışsal niyetler üzerindeki etkisinin anlaşılmasını amaçlamışlardır. Kim ve arkadaşları (2021) da ürünlerin sadece sürdürülebilir bir şekilde tasarlanması ve üretilmesinin değil, aynı zamanda israfı en aza indirmek için tüketiciler arasında mümkün olduğunca uzun süre dolaşmasının gerekliliğini dile getirmekte ve döngüsel modanın endüstrisinin gelecekteki trend olacağını düşünmektedir.

İkinci el alışverişe yönelik yapılan çalışmalarda elde edilen bulgulara göre, bazı tüketicilerin ekonomik nedenlerden dolayı ikinci el tüketime katıldığg (Sihvonen ve Turunen, 2016; Joung ve Park-Poaps, 2013), bazı tüketicilerin ise eğlence arayışı, sosyalleşme ve en iyi ürünü bulmak isteme gibi nedenlerle çevrimiçi ikinci el alışveriş sitelerini kullandıkları tespit edilmiştir (William ve Paddock, 2003; Chu ve Liao, 2007). İkinci el alışverişin kaynak verimliliğine etkisi, sürdürülebilirlik üzerine yapılan çalışmalara bakıldığında ise; çevresel faktörlerin çok da etkili olmadığı sonucuna varılmış olup ikinci el alışveriş sitelerini kullanan tüketicilerin 
çevre bilinci, döngüsel moda, sürdürülebilirlik gibi konulara eğilimleri olmasına rağmen çevrimiçi ikinci el alışveriş yaparken bu özellikleri göstermedikleri düşünülmektedir (Cervellon vd., 2012). Amatulli ve arkadaşlarının 2018 yılında yaptıkları çalışmalarında ise tam tersi bir sonuca ulaşmışlardır. Çalışmalarında tüketicilerin çevre bilinciyle hareket ederek ikinci el ürünlere yöneldiklerini belirtmiş olmalarına rağmen genel olarak hedonik faktörlerin etkili olduğu sonucuna ulaşılmıştır. Alışverişte eğlence boyutunun daha ön planda olduğu etkileşimlerin yaşandığı ve tüketicilerin bu etkileşimlerden dolayı ikinci el alışveriş sitelerini kullandıkları düşünülmektedir (Clausen vd., 2010).

\subsection{Satın Alma Tarzları ve Davranışlar}

Crowley ve arkadaşları (1992) ürünleri hedonik ve faydacı olarak sınıflandırılmıştır. Babin, Darden ve Griffin 1994'de hedonistik ve faydacı tüketim ölçeği geliştirmişlerdir. Bu ölçekte hedonik tüketimi eğlence ve faydacı tüketimi de görev ile özdeşleştirmişlerdir. Pazarlamacıların hedonik tüketimi tüketicilere nasıl pazarladıkları üzerine O'Shaughnessy ve O'Shaughnessy (2002) tarafından yapılan araştırmada soyut fayda olarak algıladıkları hazzı tatmin etmek için satın alma davranışı gerçekleştirdikleri ortaya koyulmuştur.

Satın alma eğilimlerine yönelik olan çalışmalarda ise çevrimiçi alışverişin artmasıyla birlikte 2017'de Moon ve diğerleri satıcıların stratejilerini oluştururken sadece faydacı özellikleri değil hedonik özelliklerin de dikkate alması gerektiği sonucuna varmışlardır. 2021 yılında Kim ve arkadaşları ikinci el ürünler ile ilgili yaptıkları araştırmada ikinci el ürün hakkında tüketicilerin duyduğu endişenin azaltılması ve ikinci ele tüketicilerin nasıl ve ne şekilde teşvik edildikleri üzerine çalışmış olup tüketicilerin niyetlerini incelemişlerdir. İkinci el ürünün geçmişi hakkında bilgi sahibi olan tüketicilerin ürünün geçmişi hakkında bilgi sahibi olması, hizmete ve hizmetin algılanan hedonik, sosyal ve ekonomik faydalarına olan güvenini arttırdığını tespit etmişlerdir. Kompulsif satın alma ile ilgili yapılan bazı çalışmalarda çoğunlukla gençlerin (Dittmar, 2005), bazı çalışmalarda ise genç kadınların kompulsif satın alma eğilimlerinin diğer kişilere göre daha fazla olduğu tespit edilmiş olsa da (Shoham ve Brencic, 2003; Guo ve Cai,2011) birtakım çalışmalarda ise kompulsif satın alma eğilimi ve cinsiyet arasında anlamlı bir ilişki bulunamamıştır (Balabanis, 2002; Sneath vd., 2009). Kompulsif satın alma davranışı gösteren kişiler ile kredi kartı kullanımı arasında ilişki olduğu tespit edilmiştir (Roberts ve Jones, 2001; Park ve Burns, 2005). Kukar-Kinney ve arkadaşları (2009) kompulsif satın alma eğilimi ile çevrimiçi satın alma motivasyonları arasında pozitif bir ilişki bulunduğunu saptamışlardır. Kukar-Kinney ve arkadaşları 2012 yılında yaptıkları çalışmada ise kompulsif tüketicilerin ürünlerin fiyatları hakkında daha fazla bilgiye ve kompulsif olmayan tüketicilere kıyasla daha fazla marka ve fiyat bilincine sahip aynı zamanda prestije duyarlı olduklarını tespit etmiştir.

Turunen ve arkadaşları (2019) konuyu tüketici gözünden değil de satıcı gözünden incelemiştir. Çevrimiçi ikinci el alışveriş platformlarında C2C (tüketiciden tüketiciye) yöntemiyle satış yapıldığından dolayı sonuç olarak gene nihai tüketici ile çalışma yapılmıştır. İkinci el lüks ürün satan tüketicilerin toplumsal rolünün, sınıfının değiştiği yönünde bir algı söz konusudur. İkinci el lüks ürün satma eylemini gerçekleştiren tüketicilerin daha yüksek bir sosyal statüye sahip olduğu algısı ortaya çıkmaktadır. Kessous ve Florence (2019) tüketicilerin özgüvenlerini artırmak, ait olma ihtiyaçlarını karşılamak ve sosyal statülerini yukarı taşımak için ikinci el lüks ürünler satın alma eğiliminde olduklarını tespit etmiştir. İlk elden lüks ürün satın alan tüketicilerin ise tersine güçlerini gösterme, sosyal tanınma arayışı ve bir uzman olarak tanınmak isteme eğiliminde oldukları tespit edilmiştir. Achabou ve Dekhili (2013) tüketicilerin sürdürülebilirlik, döngüsel moda gibi kavramları lüks ürünlerle ne ölçüde ilişkilendirilebileceğini, geri dönüştürülmüş malzemeleri ne kadar dikkate alma eğiliminde olabileceklerini araştırdıklarında bu tür lüks ürünlerde geri dönüştürülmüş malzemelerin kullanılmasının tüketici tercihlerini olumsuz yönde etkilediğini belirlemiştir.

\subsection{Algılanan Risk, İlgilenim, Yenilikçilik}

Algılanan risk; bireyin satın alma kararı verirken sonucunu tam olarak tahmin edemediği bir belirsizlik durumudur. Bireylerin satın alma davranışını yavaşlattığından dolayı algılanan riskin incelenmesi oldukça önemlidir (Bauer, 1960 ; Stone \& Mason, 1995). Suki ve Suki (2007) yaptıkları çalışmada yeni ürün ve hizmete ilişkin olarak bireylerin algıladığı riskin yüksek olmasının yeni olanın belirsizliğinden kaynaklandığını vurgulamaktadır. Buna göre yeni ürün veya hizmet alımının risk taşıması o ürün veya hizmetin alınmayacağı veya kullanılmayacağı anlamını taşımamaktadır. Hirunyawipada ve Paswan (2006) tüketici yenilikçiliğinin algılanan riski azaltmasından dolayı aralarında ters yönlü bir ilişki olduğunu söylemektedir. Miyazaki ve Fernandez (2001) tüketicilerin güvenilirliğinden emin olduğu ve gizlilik özelliklerine sahip çevrimiçi 


\section{Gezmişoğlu Şen - G. Telli 13/3 (2021) 2587-2606}

platformlardan alışveriş yapma olasılıklarının yüksek olduğundan bahsetmektedir.

İlgilenim; bireylerin ihtiyaçları, kişisel değerleri ve ilgi alanına bağlı olarak belirli bir ürün ile bireyin algılanan ilişkisi olarak tanımlanmıştır (Zaichkowsky, 1985). Ürün ilgilenimi ile algılanan risk arasında genellikle pozitif yönlü bir ilişki söz konusudur. Laurent ve Kapferer (1985) ürünün algılanan risk düzeyinin, ürün ilgilenimi konusunda belirleyici bir etkisinin olduğunu göstermiştir. Fakat literatüre bakıldığında negatif ilişkinin de söz konusu olduğunu söylemek mümkündür. Garcia ve Kandemir (2006) tarafından yapılan çalışmada ilgilenim ile algılanan risk arasında negatif ilişki bulmuşlardır. Literatürde algılanan risk ile ilgilenim arasında yapılan çalışmaların bazısında algılanan riskin ilgilenimin öncülü olduğu sonucuna varılsa da bazı çalışmalarda da algılanan riskin ilgilenimin sonucu olduğu sonucuna varılmaktadır. Dolayısıyla fikir birliğinden söz etmek mümkün değildir. İlgilenimin, satın alma karar sürecinin tüm aşamalarında etkili olduğu yapılan araştırmalar ile ortaya konulmuştur. O'Cass (2000) ilgilenimin satın alma kararlarına da yönelik olabileceğini tespit etmiştir. Ayrıca tutum, niyet ve davranışların şekillenmesinde rol oynadığı yapılan araştırmalar ile ortaya konulmuştur (Foxall ve Bhate, 1993; Verbeke ve Vackier, 2003).

Yenilikçilik, yeniliği benimseme eylemidir. Bireylerin yenilikçi olup olmadığı, karşılaştıkları yeni ürün, hizmet veya fikri benimsemesi ile ilgilidir. Yenilikçilik düzeyleri, kişinin yenilikle karşılaşmasından sonra başlayan bir süreçtir (Goldsmith \& Foxall, 2003). İlgilenimin, yenilikçi davranış biçimi sergilemede de önemli rol oynamaktadır. İlgilenim ile yenilikçilik arasında pozitif bir ilişki söz konusudur (Goldsmith ve Hofacker, 1991).

\section{YÖNTEM}

\subsection{Hipotezler ve Araştırma Modeli}

$\mathrm{Bu}$ araştırmada ilgilenim algılanan risk ve yenilikçiliğin ikinci el satın alma davranışı (satın alma niyeti ve motivasyonuna) etki ettiği ve tüm bunların da satın alma tarzlarına etkisi ele alınmaktadır. Literatürde tüketici yenilikçiliğinin ürün ilgilenim düzeyi üzerinde kurgulandığını görülmektedir. Ürün veya hizmetin farklı olması, o ürüne karşı ilgilenim düzeyinin de arttığını göstermektedir. İkinci el çevrimiçi Pazar günümüzde yeni bir çevrimiçi pazar olmasından dolayı yapılan çalışmada bağımsız değişkenler arasında yenilikçilik ve ilgilenime yer verilmiştir.

Kişilerin satın alma davranışını etkileyen en önemli unsur algılanan risktir. Bir tüketici karşılaştığı ürün ve hizmeti diğer bir tüketici ile aynı şartlarda algılaması mümkün olmayabilir. Farklı algılama sonucunda satın alma sürecinin her aşamasında algılanan risk bulunmaktadır. Çevrimiçi ikinci el pazarında hem çok yeni bir oluşum olmasından kaynaklı hem de hem çevrimiçi olması hem de ikinci el olması yani yapısal özelliğinden dolayı risk içermektedir. Bu nedenle, araştırmada bağımsız değişkenlerin arasında algılanan risk kavramının da bulunması gerektiği düşülmüştür. Böylelikle ilgilenim, yenilikçilik ve algılanan risk kavramları araştırmanın bağımsız değişkenleridir.

Bir diğer çıkış noktası ise çevrimiçi ikinci el satın alma motivasyonudur. Çevrimiçi alışveriş yapan fakat ikinci el çevrimiçi alışveriş yapmamış olan tüketiciler için ikinci el çevrimiçi satın alma niyeti de diğer bir çıkış noktasıdır. İkinci el çevrimiçi satın alma motivasyonları ve ikinci el çevrimiçi satın alma niyeti de bağımsız değişkenlerdir.

Çalışmada bağımlı değişkeni ise satın alma tarzları (kompulsif, hedonik, faydacı) oluşturmaktadır. 


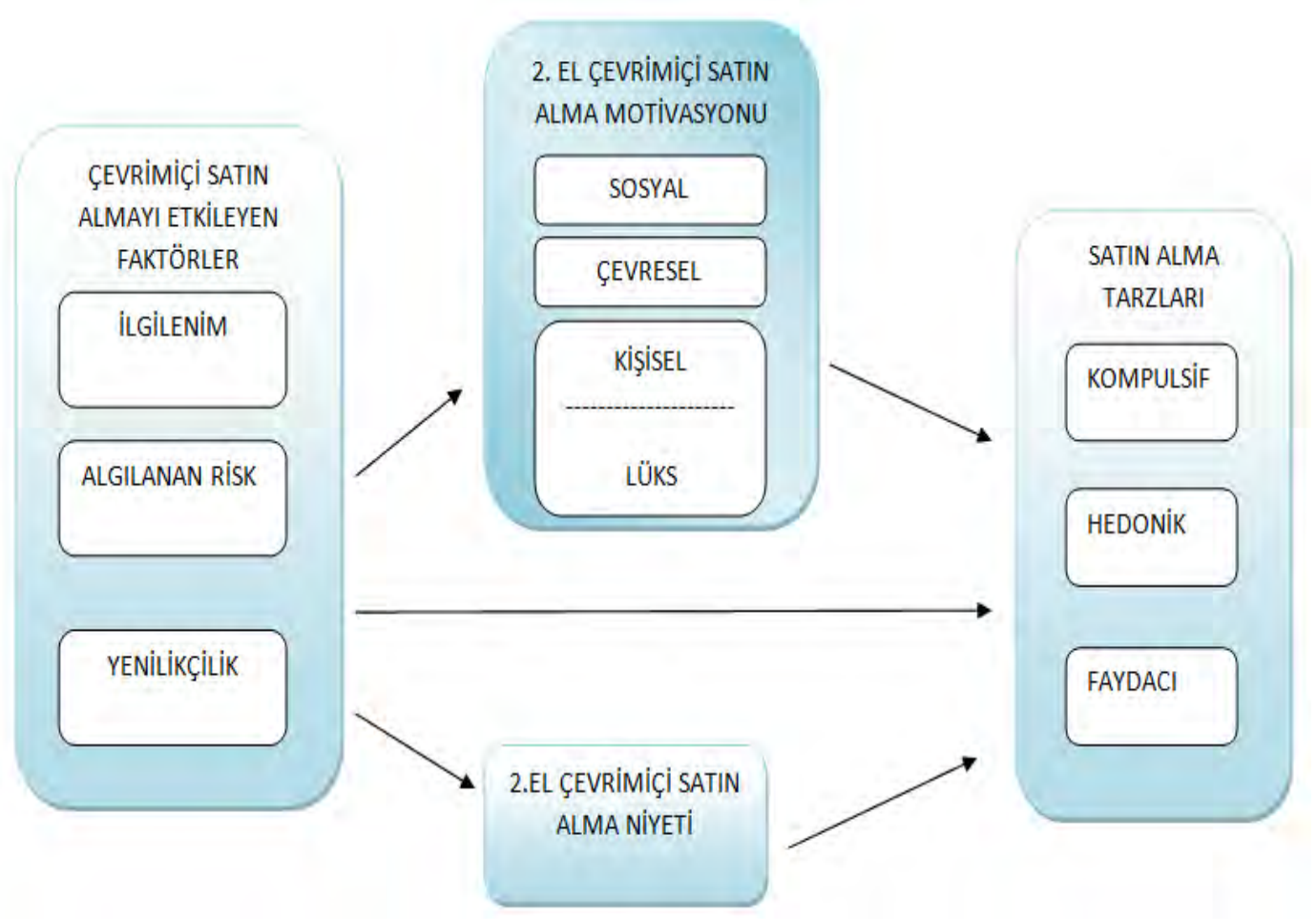

Şekil 1. Araştırma Modeli

Bu açıklamalar çerçevesinde öne sürülen hipotezler şu şekildedir;

H1a: İlgilenim ile kompulsif satın alma tarzı arasında pozitif bir ilişki bulunmaktadır.

H1b: İlgilenim ile hedonik satın alma tarzı arasında pozitif bir ilişki bulunmaktadır.

H1c: İlgilenim ile faydacı satın alma tarzı arasında pozitif bir ilişki bulunmaktadır.

H2a: Yenilikçilik ile kompulsif satın alma tarzı arasında pozitif bir ilişki bulunmaktadır.

$\mathrm{H} 2 \mathrm{~b}$ : Yenilikçilik ile hedonik satın alma tarzı arasında pozitif bir ilişki bulunmaktadır.

H2c: Yenilikçilik ile faydacı satın alma tarzı arasında pozitif bir ilişki bulunmaktadır.

H3a: Algılanan risk ile kompulsif satın alma tarzı arasında pozitif bir ilişki bulunmaktadır.

H3b: Algılanan risk ile hedonik satın alma tarzı arasında pozitifbir ilişki bulunmaktadır.

H3c: Algılanan risk ile faydacı satın alma tarzı arasında pozitif bir ilişki bulunmaktadır.

H4a: Hedonik satın alma ile ikinci el sosyal motivasyonu arasında pozitif bir ilişki bulunmaktadır.

H4b: Hedonik satın alma ile ikinci el çevresel motivasyonu arasında pozitif bir ilişki bulunmaktadır.

H4c: Hedonik satın alma ile ikinci el kişisel motivasyonu arasında pozitif bir ilişki bulunmaktadır.

H4d: Hedonik satın alma ile ikinci el lüks motivasyonunu arasında pozitif bir ilişki bulunmaktadır.

H5a: Kompulsif satın alma ile ikinci el sosyal motivasyonu arasında pozitif bir ilişki bulunmaktadır.

H5b: Kompulsif satın alma ile ikinci el çevresel motivasyonu arasında pozitif bir ilişki bulunmaktadır.

H5c: Kompulsif satın alma ile ikinci el kişisel motivasyonu arasında pozitif bir ilişki bulunmaktadır.

H5d: Kompulsif satın alma ile ikinci el lüks motivasyonunu arasında pozitif bir ilişki bulunmaktadır.

H6a: Faydacı satın alma ile ikinci el sosyal motivasyonu arasında pozitif bir ilişki bulunmaktadır.

H6b: Faydacı satın alma ile ikinci el çevresel motivasyonu arasında pozitif bir ilişki bulunmaktadır.

H6c: Faydacı satın alma ile ikinci el kişisel motivasyonu arasında pozitif bir ilişki bulunmaktadır.

H6d: Faydacı satın alma ile ikinci el lüks motivasyonunu arasında pozitif bir ilişki bulunmaktadır.

H7: Hedonik satın alma ile tüketicilerin ikinci el çevrimiçi satın alma niyeti arasında pozitif bir ilişki bulunmaktadır.

H8: Kompulsif satın alma ile tüketicilerin ikinci el çevrimiçi satın alma niyeti arasında pozitif bir ilişki bulunmaktadir.

H9: Faydacı satın alma ile tüketicilerin ikinci el çevrimiçi satın alma niyeti arasında pozitif bir ilişki bulunmaktadir. 


\subsection{Evren ve Örneklemin Belirlenmesi}

Araştırma, Türkiye'de çevrimiçi alışveriş yapan tüm tüketicileri kapsamaktadır. Araştırma Covid-19 salgını döneminde yapılmış olup kolayda örnekleme yolu tercih edilmiştir. Ulaşılan tüketicilerden çevrimiçi anket yolu ile anketleri doldurmaları ve aynı şekilde kendisi gibi çevrimiçi alışveriş yapan diğer tüketicilere de anketi iletmeleri istenmiştir. Ayrıca ikinci el ile ilgili alışveriş sitelerinden alışveriş yapan kişiler ile iletişime geçilmiş olup çevrimiçi anketleri doldurmaları ve kendisi gibi ikinci el çevrimiçi alışveriş sitelerinden alışveriş yapan kişilere iletmeleri istenmiştir. Yapılan çalışmada çeşitli çevreci platformlara (sıfır atık, minimalist yaşam platformları gibi gruplara) ulaşılmış olup çevrimiçi anket yoluyla anketleri doldurmaları istenmiş ve çevrelerindeki kendisi gibi kişilere anketleri iletmeleri istenmiştir. Bu şekilde yalnızca profile uygun katılımcıların katılımı sağlanmıştır. Araştırmanın nesnelliğini korumak amacıyla her gruptan sınırlı sayıda katılım talep edilmiştir. Çalışma neticesinde 746 anket formu elde edilmiştir. Ancak 57 katılımcının anketi eksik/hatalı doldurulduğu fark edilmiş anketten çıkarılmıştır. Böylece 689 katılımcının anket formu değerlendirmeye alınmıştır.

\subsection{Veri Toplama Aracı}

Araştırma modelinde yer alan değişkenler arasında oluşturulan hipotezlerin test edilmesine yönelik veri sağlamak amacıyla çevrimiçi anket yöntemi tercih edilmiştir. Anket formunda yer alacak değişkenlerin her biri için ölçek tespit edilmiştir. Ölçeklerin belirlenmesi aşamasında alanında kabul görmüş, geçerlilik ve güvenilirlikleri sağlanmış ölçeklerin tercih edilmesine dikkat edilmiştir. Veri toplama aşamasına geçilmeden önce Maltepe Üniversitesi Etik Komisyonundan gerekli onay alınmıştır (Karar No:2021/10-07).

- İlgilenim ölçeği Svein Ottar Olsen (2007) tarafından Mittal (1995) ve Shim (2000) ölçeklerine dayandırılarak,

- Yenilikçilik ölçeği Völckner/Sattler (2006) tarafından Hem ve arkadaşları (2001), Klink ve Smith (2001) ve Midgley ve Dowling (1978) ölçeklerine dayandırılarak,

- Algılanan risk ölçeği Laroche ve arkadaşları (2005) tarafından Stone ve Gronhaug (1993) ölçeğine dayandirılarak,

- İkinci el satın alma ölçeği Steffen (2016) tarafından Guiot ve Roux (2010) ölçeğine dayandırılarak,

- Çevrimiçi satın alma niyeti ölçeği Vijayasarathy (2003) tarafından Davis (1989) teknoloji kabul modeline dayandırılarak geliştirilen ölçek,

- Çevrimiçi kompulsif satın alma ölçeği Ridgway ve arkadaşları (2008) tarafından geliştirilen Richmond kompulsif satın alma ölçeği,

- Çevrimiçi hedonik ve faydacı satın alma ölçeği Babin, Darden ve Griffin (1994) geliştirilen ölçek kullanılmıştır.

\subsection{Verilerin Analizi}

Anket formlarından elde edilen veriler SPSS 22.0 paket programı kullanılarak analiz edilmiştir. Daha sonra araştırma analizi kapsamında, güvenilirlik analizi, keşfedici faktör analizi ve regresyon analizleri yapılarak araştırmanın hipotezleri test edilmiştir. 


\section{BULGULAR}

Ankete 746 yanıt olmakla birlikte ankete katılan 689 katılımcının formları dikkate alınmıştır. Katılımcıların cinsiyet, yaş, çocuk sayısı, çalışma durumu, medeni durum, gelir durumu ve eğitim durumuna ilişkin olmak üzere tanımlayıı bilgi olarak nitelenen demografik bilgileri Tablo1'de sunulmuştur.

Tablo1.Örneklemin demografik profili $(\mathrm{N}=689)$

\begin{tabular}{|c|c|c|c|c|c|}
\hline Demografik Özellikler & Siklık & $\begin{array}{l}\text { Oran } \\
(\%)\end{array}$ & & Siklık & Oran (\%) \\
\hline \multicolumn{6}{|l|}{ Cinsiyet } \\
\hline Kadın & 660 & 95,8 & Medeni Durum & & \\
\hline Erkek & 29 & 4,2 & Evli & 330 & 47,9 \\
\hline Yas & & & Bekar & 359 & 52,1 \\
\hline $18-28$ & 306 & 44,4 & Gelir Durumu & & \\
\hline $29-38$ & 281 & 40,8 & 3000 TL ve alt1 & 272 & 39,5 \\
\hline $39-48$ & 86 & 12,5 & $3001-4000$ & 78 & 11,3 \\
\hline $49-58$ & 16 & 2,3 & $4001-5000$ & 102 & 14,8 \\
\hline Çocuk Sayısı & & & $5001-6000$ & 70 & 10,2 \\
\hline 0 & 455 & 66,0 & $6001-7000$ & 50 & 7,3 \\
\hline 1 & 138 & 20,0 & 7001 ve üzeri & 117 & 17,0 \\
\hline 2 & 75 & 10,9 & Eğitim Durumu & & \\
\hline \multirow[t]{2}{*}{3 ve üzeri } & 21 & 3,0 & İlköğretim & 6 & 0,9 \\
\hline & & & Lise & 58 & 8,4 \\
\hline ÇalışmaDurumu & & & Yüksekokul & 86 & 12,5 \\
\hline Çalışıyor & 380 & 55,2 & Lisans & 387 & 56,2 \\
\hline Çalışmıyor & 256 & 37,2 & Yüksek Lisans & 152 & 22,1 \\
\hline Freelance & 38 & 5,5 & & & \\
\hline Part-time & 15 & 2,2 & & & \\
\hline
\end{tabular}

Demografik özelliklerine bakıldığında 689 kişinin \%95,8'i kadın, \%4,2'si erkek katılımcılardan oluştuğu, medeni durum olarak\%47,9'unun evli, \%52,1'inin bekar olduğu tespit edilmiştir. Katılımcıların \%44,4 ile 1828 yaş aralığında; \%40,8 ile 29-38 yaş aralıklarında olduğu belirlenmiştir. Katılımcıların çocuk sayısına bakıldığında çoğunluğun \%66,0 ile çocuk sahibi olmadığ1; \%20,0 ile bir çocuğa sahip oldukları tespit edilmiştir. Katılımcıların \%55,2'sinin çalıştığı, \%37,2'sinin ise çalışmadığı kalan yüzdenin ise yarı zamanlı çalışan kişilerden oluştuğu tespit edilmiştir. Katılımcıların \%39,5'i 3.000TL ve altında gelire sahip iken \%14,8'1 4001 ve $5000 \mathrm{TL}$ arasında gelire sahiptir. Eğitim durumlarına göre ilk sırada \%56,2 ile lisans mezunları, \%22,1 ile yüksek lisans mezunları ikinci sırada yer alırken bunu sırasıyla, ön lisans ve lise mezunları bulunmaktadır. Elde edilen sonuçlarda katılımcıların eğitim seviyelerinin yüksek olduğu ortaya çıkmıştır.

Katılımcılara ikinci el çevrimiçi alışveriş yapıp yapmadıkları sorulmuş \%48,5 katılımcının ikinci el çevrimiçi alışveriş yaptığ 1 ve \%51,5 katılımcının ise sadece birinci el çevrimiçi alışveriş yaptı̆̆ tespit edilmiştir.

Katılımcılara ne sıklıkla alışveriş yaptıkları sorulduğunda yoğunlukların \%43,7 ile ayda birkaç defa yaptıkları ve bunu sırasıyla yılda birkaç defa ile ayda bir defa takip etmektedir. Katılımclların \%40,1'i hem ikinci el ürün hem de binci el ürün alabileceklerini söylemektedirler. Buradaki tercihi, "ürünün ne olduğu" belirlemektedir.

Katılımcılara ikinci el lüks ürün satın alıp almadıkları ile bilgili soru yönlendirilmiş olup, ikinci el alışveriş yapan tüketicilerin \%30,2'si ikinci el lüks ürün satın almazken \%18,3'ünün ikinci el lüks ürün satın aldıkları tespit edilmiştir. Lüks ürün satın alan tüketicilerin demografik özellikleri incelendiğinde \%94,4'ünü kadın, \%5,6'sını erkek katılımclar oluşturmaktadır. Yaş grupları incelendiğinde yoğunluklarının \%46,0 ile 29-38 yaş aralığında, \%35,7 ile 18-28 yaş aralıklarında olduğu tespit edilmiştir. İkinci el çevrimiçi lüks ürün satın alan katılımcıların \%57,21'inin çalıştığı ve \%57,9'unun çocuğu olmadığı tespit edilmiştir. Katılımcıların \%31'i 3.000TL ve altında gelire sahip iken $\% 17,5^{\prime}$ inin 4001 ve $5000 \mathrm{TL}$ arasında gelire sahip olduğu görülmektedir. İkinci el çevrimiçi lüks ürün satın alan tüketicilerin \%52,4'ünün eğitim seviyesinin yüksek lisans düzeyinde olduğu tespit edilmiştir. 
Katılımcıların en çok kullandığı çevrimiçi ikinci el siteleri sırasıyla \%33,5 ile dolap, \%23,4 ile letgo, \%14,6 ile gardrop ve $\% 13,8$ ile sahibinden olduğu tespit edilmiştir. Katılımcılara ikinci el alışverişe nasıl başladıklarını sorulduğunda katılımcıların \%40,2'sinin internette sörf yaparken olduğu anlaşılmıştır. Katılımcıların \%30,3'ü ise arkadaş tavsiyesi ile çevrimiçi ikinci el alışveriş yaptıklarını söylemektedirler. Katılımcıların \%20,7'si ise bu siteleri internet reklamlarında gördügünü söylemektedirler.

Katılımcılara ikinci el tercih sebepleri sorulduğunda yoğunlukları \%26 ile kişilerin hem alıcı hem de satıcı olabilme imkanının cazip geldiği bu yüzden ikinci el çevrimiçi sitelerini kullandıkları tespit edilmiş olup, sırasıyla \%20,9 ile fiyat karşılaştırması, $\% 15,1$ ile ödeme sistemlerinin güvenli olması ve $\% 10,1$ ile anlık alışveriş imkanının bulunması olarak tespit edilmiştir. Katılımcıların ürünü teslim alma seçeneklerine bakıldığında $\% 42,6$ 's ' hem kargo ile hem de elden teslim alabilirim demiştir. Fiyatına göre iki seçenekten birini kullanmak istemektedirler. Katılımcıların \%42,1'i ise sadece kargo ile teslim almak istemekte olup \%15,4'ü ise elden teslim almak istemektedirler. Katılımcıların ödeme tercihlerine bakıldığında \%46,5 ile kredi kartı ile ödemeyi seçtikleri tespit edilmiştir. Sırasıyla \%18,3 banka transferi, \%17,6 nakit ve \%17,6 ise kapıda ödeme seçeneğini kullanmak istemektedir. Bu sonuca göre, tüketicilerin çevrimiçi alışveriş sitelerinin ödeme sistemlerine güvendikleri tespit edilmiştir. Böylelikle yoğunluklu olarak çevrimiçi tüketicilerin kredi kartı ile alışveriş yapıp kargo ile teslim almak istemektedirler.

\subsection{Keşfedici Faktör Analizi}

Bu çalışmada, mevcut literatürden yola çıkarak, elde edilen değişkenler kullanılmıştır. Faktör yapısının keşfedilmesi amaçlandığı için de keşfedici faktör analizi ile faktör boyutları belirlenmiştir.

Tablo 2. Faktör ve Güvenilirlik Analizi Sonuçları

\begin{tabular}{|c|c|c|c|c|c|}
\hline Değişkenler & Faktör Yükü & $\begin{array}{l}\text { Cronbach's } \\
\text { Alpha }(\alpha)\end{array}$ & Değişkenler & Faktör Yükü & $\begin{array}{l}\text { Cronbach's } \\
\text { Alpha }(\alpha)\end{array}$ \\
\hline İE/ SOSYAL (1) &, 592 & 0,722 & KOM1 & ,750 & 0,812 \\
\hline İE/ SOSYAL (2) &, 528 & & KOM2 & 780 & \\
\hline İE/ SOSYAL (3) & 852 & & KOM3 & 660 & \\
\hline İE/ SOSYAL (4) & 849 & & HED1 & 715 & 0,901 \\
\hline İE/ÇEVRESEL (1) & 821 & 0,688 & HED2 &, 595 & \\
\hline İE/ÇEVRESEL (2) & ,818 & & HED3 & 610 & \\
\hline İE/ÇEVRESEL (3) & 819 & & HED4 & 739 & \\
\hline İE/Kİ̧iSEL (1) & 633 & 0,651 & HED5 & 672 & \\
\hline İE/KİŞİSEL (2) & 776 & & HED6 & ,569 & \\
\hline İE/KİŞİSEL (3) & 715 & & HED7 & 790 & \\
\hline İE/LÜKS (1) & 600 & 0,593 & HED8 & 613 & \\
\hline İE/LÜKS (2) & 626 & & HED9 & 725 & \\
\hline İE/LÜKS (3) & 730 & & HED10 & ,744 & \\
\hline ILLG1 & 832 & 0,917 & HED11 & ,707 & \\
\hline İLG2 & 891 & & HED12 &, 542 & \\
\hline İLG3 & 882 & & FAY1 & 652 & 0,502 \\
\hline İLG4 & 838 & & FAY2 & 828 & \\
\hline YEN1 & 816 & 0,844 & İEN1 & 857 & 0,857 \\
\hline YEN2 & 768 & & İEN2 & 870 & \\
\hline YEN3 & 796 & & İEN3 & 821 & \\
\hline ALG1 & 876 & 0,740 & İEN4 & 770 & \\
\hline ALG2 & 869 & & & & \\
\hline ALG3 & 610 & & & & \\
\hline
\end{tabular}

Varimax rotasyonunun kullanıldığı analiz sonucunda Keiser - Meyer - Olkin örneklem yeterliliği ölçümü ve Barlett küresellik testi sonuçları incelenmiştir. Yapılan çalışmada, Bartlett testi anlamlı $(\mathrm{p}<0.05)$ ve KMO değerinin 0.50 'den büyük olduğu tespit edilmiştir $(\mathrm{KMO}=, 882)$. 


\subsection{Regresyon Analizi}

"İlgilenim ile kompulsif satın alma tarzı arasında pozitif bir ilişki bulunmaktadır", "Yenilikçilik ile kompulsif satın alma tarzı arasında pozitif bir ilişki bulunmaktadır" ve "Algılanan risk ile kompulsif satın alma tarzı arasında pozitif bir ilişki bulunmaktadır" şeklinde düzenlenen H1a, H2a ve H3a hipotezlerini incelemek için yapılan regresyon analizi ve test sonuçları Tablo 3'te gösterilmiştir. F değerinin 85,337 ve $F$ anlamlılık değerinin ise $0,000(p<0,05)$ olması dolayısıyla, regresyon modelinin istatistiksel olarak anlamlı olduğu görülmektedir. Analiz sonuçlarına göre algılanan risk $(\beta=0.260, p<0.05)$ ile anlamlı bir ilişki tespit edilememiştir. H3a hipotezi reddedilmiştir. Yenilikçilik $(\beta=0.330, \mathrm{p}<0.001)$ ve ilgilenim $(\beta=0.182, \mathrm{p}<0.001)$ kompulsif satın alma üzerinde etkili oldukları görülmektedir. R²0,272 olduğu görülmektedir. Yenilikçilik ve ilgilenim boyutlarının, kompulsif satın almanın $\% 27,2$ 'sini anlamlı olarak açıklamaktadır. Elde edilen sonucun H1a ve H2a hipotezlerinin desteklendiğini göstermektedir.

Tablo 3. Regresyon Analizi (N:689)

\begin{tabular}{lll}
\hline & Bağımlı değişken: Kompulsif satın alma & \\
\hline Bağımsız değişken & $\beta$ & $\mathbf{p}$ \\
\hline Algılanan risk &, 260 & 476 \\
Yenilikçilik &, 330 &, 000 \\
İlgilenim &, 182 &, 000 \\
\hline $\mathbf{R}$ &, 522 & \\
$\mathbf{R}^{2}$ &, 272 &, 000 \\
$\mathbf{F}$ & 85,337 & \\
\hline
\end{tabular}

Kompulsif satın alma ile tüketicilerin ikinci el çevrimiçi satın alma niyeti arasında pozitif bir ilişki bulunmaktadır" şeklinde düzenlenen H8 hipotezini incelemek için yapılan regresyon analizi ve test sonuçları Tablo $4^{\prime}$ te gösterilmiştir. F değerinin 1,347 ve F anlamlılık değerinin ise $0,000(p<0,05)$ olması dolayısıyla, regresyon modelinin istatistiksel olarak anlamlı olduğu görülmektedir. Fakat bu modelde bağımsız değişken ikinci el çevrimiçi satın alma niyetidir. İkinci el çevrimiçi satın alma niyeti $(\beta=-0.061 ; p>0.05)$ ile kompulsif satın alma arasında istatistiki olarak pozitif bir ilişki tespit edilmemiştir. Bu bağlamda H8 hipotezi desteklenmemektedir.

Tablo 4. Regresyon Analizi (N:355)

Bağımlı değişken: Kompulsif satın alma

\begin{tabular}{lll}
\hline Bağımsız değişken & $\boldsymbol{\beta}$ & $\mathbf{p}$ \\
\hline Niyet &,- 061 &, 247 \\
\hline $\mathbf{R}$ &, 062 & \\
$\mathbf{R}^{2}$ &, 004 &, 000 \\
$\mathbf{F}$ & 1,347 & \\
\hline
\end{tabular}

"Kompulsif satın alma ile ikinci el sosyal motivasyonu arasında pozitif bir ilişki bulunmaktadır", "Kompulsif satın alma ile ikinci el çevresel motivasyonu arasında pozitif bir ilişki bulunmaktadır" ve "Kompulsif satın alma ile ikinci el kişisel motivasyonu arasında pozitif bir ilişki bulunmaktadır" şeklinde düzenlenen H5a, H5b ve H5c hipotezlerini incelemek için yapılan regresyon analizi ve test sonuçları Tablo 5 'te gösterilmiştir. F değerinin 6,334 ve F anlamlılık değerinin ise $0,000(p<0,05)$ olması dolayısıyla, regresyon modelinin istatistiksel olarak anlamlı olduğu görülmektedir. Bu modelde bağımsız değişkenlere ikinci el sosyal motivasyon, ikinci el çevresel motivasyon ve ikinci el kişisel motivasyon eklenmiştir. İkinci el çevresel motivasyon $(\beta=-0.237$, $\mathrm{p}<0.05)$ ve ikinci el kişisel motivasyon $(\beta=-0.016, p<0.05)$ arasında pozitif bir ilişki tespit edilememiştir. H5b ve H5a hipotezleri reddedilmiştir. İkinci el sosyal motivasyon $(\beta=0.0187, \mathrm{p}<0.05)$ ile kompulsif satın alma üzerinde etkili olduğu görülmektedir. H5a hipotezi desteklenmektedir. 
D. Gezmişoğlu Şen - G. Telli 13/3 (2021) 2587-2606

Tablo 5.Regresyon Analizi (N:334)

\begin{tabular}{lcc}
\hline & Bağımlı değişken: Kompulsif satın alma & \\
\hline Bağımsız değişken & $\boldsymbol{\beta}$ & $\mathbf{p}$ \\
\hline Sosyal &, 0187 &, 007 \\
Çevresel &,- 237 &, 000 \\
Kişisel &,- 016 &, 845 \\
\hline $\mathbf{R}$ &, 233 & \\
$\mathbf{R}^{2}$ &, 054 &, 000 \\
$\mathbf{F}$ & 6,334 & \\
\hline
\end{tabular}

"Kompulsif satın alma ile ikinci el lüks motivasyon arasında pozitif bir ilişki bulunmaktadır" şeklinde düzenlenen H5d hipotezini incelemek için yapılan regresyon analizi ve test sonuçları Tablo 6' da gösterilmiştir.

Tablo 7' de yer alan verilerden ANOVA test sonucu incelendiğinde; F değerinin 9,779 ve F anlamlılık değerinin ise $0,002(p<0,05)$ olması dolayısıyla, regresyon modelinin istatistiksel olarak anlamlı olduğu görülmektedir. $\mathrm{R}^{2}$ 0,073 olduğu görülmektedir. İkinci el lüks motivasyon boyutunun, kompulsif satın almanın \%7,3’ünün anlamlı olarak açıklamaktadır. Bu modelde bağımsız değişkenlere ikinci el lüks motivasyon eklenmiştir. İkinci el lüks motivasyon $(\beta=314, p<0.05)$ ile kompulsif satın alma üzerinde etkili olduğu görülmektedir. H5d hipotezi desteklenmektedir.

Tablo 6.Regresyon Analizi (N:126)

\begin{tabular}{lcc}
\hline \multicolumn{3}{c}{ Bağımlı değişken: Kompulsif satın alma } \\
\hline Bağımsız değişken & $\beta$ & $\mathbf{p}$ \\
\hline Lüks &, 314 &, 002 \\
\hline $\mathbf{R}$ &, 0270 & \\
$\mathbf{R}^{2}$ &, 073 &, 002 \\
$\mathbf{F}$ & 9,779 & \\
\hline
\end{tabular}

"İlgilenim ile hedonik satın alma tarzı arasında pozitifbir ilişki bulunmaktadır", "Yenilikçilik ile hedonik satın alma tarzı arasında pozitif bir ilişki bulunmaktadır "ve "Algılanan risk ile hedonik satın alma tarzı arasında pozitif bir ilişki bulunmaktadır" şeklinde düzenlenen $\mathrm{H} 1 \mathrm{~b}, \mathrm{H} 2 \mathrm{~b}$ ve H3b hipotezlerini incelemek için yapılan regresyon analizi ve test sonuçları Tablo 7'de gösterilmiştir. F değerinin 82,195 ve F anlamlılık değerinin ise $0,000(p<0,05)$ olması dolayısıyla, regresyon modelinin istatistiksel olarak anlamlı olduğu görülmektedir. Algılanan risk $(\beta=0.129$, $\mathrm{p}<0.001)$, yenilikçilik $(\beta=0.313, \mathrm{p}<0.001)$ ve ilgilenim $(\beta=0.143, \mathrm{p}<0.001)$ ile hedonik satın alma üzerinde etkili oldukları görülmektedir. $\mathrm{R}^{2}$ 0,261 değeri olduğu görülmektedir. Yenilikçilik, algılanan risk ve ilgilenim boyutlarının, hedonik satın almanın \%26,1'ini anlamlı olarak açıkladığı görülmektedir. H1b, H2b ve H3b hipotezleri desteklenmektedir.

Tablo 7.Regresyon Analizi (N:689)

\begin{tabular}{lcc}
\hline & Bağımlı değişken: Hedonik satın alma & \\
\hline Bağımsız değişken & $\boldsymbol{\beta}$ & $\mathbf{p}$ \\
\hline İlgilenim &, 143 &, 000 \\
Yenilikçilik &, 313 &, 000 \\
Algılanan risk &, 129 &, 000 \\
\hline $\mathbf{R}$ &, 514 & \\
$\mathbf{R}^{2}$ &, 261 &, 000 \\
$\mathbf{F}$ & 82,195 & \\
\hline
\end{tabular}

"Hedonik satın alma ile tüketicilerin ikinci el çevrimiçi satın alma niyeti arasında pozitif bir ilişki bulunmaktadır" şeklinde düzenlenen H7 hipotezini incelemek için yapılan regresyon analizi ve test sonuçları Tablo 8'de gösterilmiştir. Bu modelde bağımsız değişkenlere ikinci el çevrimiçi satın alma niyeti ilave edilmiştir. İkinci el çevrimiçi satın alma niyeti $(\beta=-0.034 ; p>0.05)$ ile hedonik satın alma arasında istatistiki olarak pozitif bir ilişki tespit edilmemiştir.H7 hipotezi desteklenmemektedir. 
D. Gezmişoğlu Şen - G. Telli 13/3 (2021) 2587-2606

Tablo 8.Regresyon Analizi (N:355)

\begin{tabular}{lll}
\hline \multicolumn{3}{c}{ Bağımlı değişken: Hedonik satın alma } \\
\hline Bağımsız değişken & $\beta$ & $p$ \\
\hline Niyet &,- 034 &, 504 \\
\hline $\mathbf{R}$ &, 36 & \\
$\mathbf{R}^{2}$ &, 01 &, 504 \\
$\mathbf{F}$ &, 447 & \\
\hline
\end{tabular}

Tablo 9'da yer alan verilerden ANOVA test sonucu incelendiğinde; $F$ değerinin 7,388 ve $F$ anlamlılık değerinin ise $0,000(\mathrm{p}<0,05)$ olması dolayısıyla, regresyon modelinin istatistiksel olarak anlamlı olduğu görülmektedir. Bu modelde bağımsız değişkenlere ikinci el sosyal motivasyon, ikinci el çevresel motivasyon ve ikinci el kişisel motivasyon eklenmiştir. İkinci el sosyal motivasyon $(\beta=0.314, p<0.05)$ hedonik satın alma üzerinde etkili oldukları görülmektedir. H4a hipotezi desteklenmektedir. İkinci el çevresel motivasyon $(\beta=-0.190, p<0.05)$, ikinci el kişisel motivasyon $(\beta=-0.079, \mathrm{p}<0.05)$ ile hedonik satın alma arasında pozitif bir ilişki tespit edilememiştir. $\mathrm{H} 4 \mathrm{~b}$ ve $\mathrm{H} 4 \mathrm{c}$ hipotezleri desteklenmemektedir.

Tablo 9. Regresyon Analizi (N:334)

\begin{tabular}{lcc}
\hline \multicolumn{3}{c}{ Bağımlı değişken: Hedonik satın alma } \\
\hline Bağımsız değişken & $\beta$ & $\mathbf{p}$ \\
\hline Sosyal &, 314 &, 000 \\
Çevresel &,- 190 &, 001 \\
Kişisel &,- 079 &, 285 \\
\hline $\mathbf{R}$ &, 552 & \\
$\mathbf{R}^{2}$ &, 305 &, 000 \\
$\mathbf{F}$ & 7,388 & \\
\hline
\end{tabular}

"Hedonik satın alma ile ikinci el lüks motivasyon arasında pozitif bir ilişki bulunmaktadır" şeklinde düzenlenen H4d hipotezini incelemek için yapılan regresyon analizi ve test sonuçları Tablo 10'da gösterilmiştir.

Tablo 11'de yer alan verilerden ANOVA test sonucu incelendiğinde; $\mathrm{F}$ değerinin 11,879 ve $\mathrm{F}$ anlamlılık değerinin ise $0,000(p<0,05)$ olması dolayısıyla, regresyon modelinin istatistiksel olarak anlamlı olduğu görülmektedir. İkinci el lüks motivasyon $(\beta=301, p<0.001)$ ile hedonik satın alma üzerinde etkili olduğu görülmektedir.H4d hipotezi desteklenmektedir.

Tablo 10. Model 2.4. Regresyon Analizi (N:126)

\begin{tabular}{lcc}
\hline \multicolumn{3}{c}{ Bağımlı değişken: Hedonik satın alma } \\
\hline Bağımsız değişken & $\boldsymbol{\beta}$ & $\mathbf{p}$ \\
\hline Lüks &, 301 &, 001 \\
\hline $\mathbf{R}$ &, 0296 & \\
$\mathbf{R}^{2}$ &, 087 &, 000 \\
$\mathbf{F}$ & 11,879 & \\
\hline
\end{tabular}

"İlgilenim ile faydacı satın alma tarzı arasında pozitif bir ilişki bulunmaktadı"," "Yenilikçilik ile faydacı satın alma tarzı arasında pozitif bir ilişki bulunmaktadır "ve "Algllanan risk ile faydacı satın alma tarzı arasında pozitif bir ilişki bulunmaktadır" şeklinde düzenlenen $\mathrm{H} 1 \mathrm{c}, \mathrm{H} 2 \mathrm{c}$ ve $\mathrm{H} 3 \mathrm{c}$ hipotezlerini incelemek için yapılan regresyon analizi ve test sonuçları Tablo 11'de gösterilmiştir.Algılanan risk $(\beta=-, 89 \mathrm{p}<0.05)$, yenilikçilik $(\beta=-0.107, \mathrm{p}<0.05)$ ve ilgilenim $(\beta=-0.19, \mathrm{p}<0.05)$ ile faydacı satın alma üzerinde bir ilişki tespit edilememiştir. H1c, H2c ve H3c hipotezleri reddedilmiştir. 
D. Gezmişoğlu Şen - G. Telli 13/3 (2021) 2587-2606

Tablo11.Regresyon Analizi (N:689)

\begin{tabular}{lll}
\hline \multicolumn{3}{c}{ Bağımlı değişken: Faydacı satın alma } \\
\hline Bağımsız değişken & $\beta$ & $\mathbf{p}$ \\
\hline Algılanan risk &,- 89 &, 032 \\
Yenilikçilik &,- 107 &, 001 \\
İlgilenim &,- 019 &, 556 \\
\hline $\mathbf{R}$ &, 170 &, 000 \\
$\mathbf{R}^{2}$ &, 029 & \\
$\mathbf{F}$ & 6,781 & \\
\hline
\end{tabular}

"Faydacı satın alma ile tüketicilerin ikinci el çevrimiçi satın alma niyeti arasında pozitif bir ilişki bulunmaktadır" şeklinde düzenlenen $\mathrm{H} 9$ hipotezini incelemek için yapılan regresyon analizi ve test sonuçları Tablo 12 'de gösterilmiştir. Bu modelde bağımsız değişkenlere ikinci el çevrimiçi satın alma niyeti ilave edilmiştir. İkinci el çevrimiçi satın alma niyeti $(\beta=-0.99 ; \mathrm{p}>0.05)$ ile faydacı satın alma arasında istatistiki olarak pozitif bir ilişki tespit edilmemiştir. H9 hipotezi desteklenmemektedir.

Tablo12.Regresyon Analizi (N:355)

\begin{tabular}{lcc}
\hline & Bağımlı değişken: Faydacı satın alma & \\
\hline Bağımsız değişken & $\beta$ & $\mathbf{p}$ \\
\hline Niyet &, 099 &, 086 \\
\hline $\mathbf{R}$ &, 088 & \\
$\mathbf{R}^{2}$ &, 008 &, 000 \\
$\mathbf{F}$ & 2,736 & \\
\hline
\end{tabular}

"Faydacı satın alma ile ikinci el sosyal motivasyonu arasında pozitif bir ilişki bulunmaktadır", "Faydacı satın alma ile ikinci el çeoresel motivasyonu arasında pozitif bir ilişki bulunmaktadır" ve "Faydacı satın alma ile ikinci el kişisel motivasyonu arasında pozitif bir ilişki bulunmaktadır" şeklinde düzenlenen H6a, H6b ve H6c hipotezlerini incelemek için yapılan regresyon analizi ve test sonuçları Tablo $13^{\prime}$ te gösterilmiştir.Tablo $13^{\prime}$ te yer alan verilerden ANOVA test sonucu incelendiğinde; $F$ değerinin 1,087 ve $F$ anlamlılık değerinin ise $0,000(p<0,05)$ olması dolayısıyla, regresyon modelinin istatistiksel olarak anlamlı olduğu görülmektedir. İkinci el sosyal motivasyon $(\beta=0.119, \mathrm{p}<0.05)$, ikinci el çevresel motivasyon $(\beta=0.24, \mathrm{p}<0.05)$ ve ikinci el kişisel motivasyon $(\beta=-$ $0.52, \mathrm{p}<0.05)$ ile faydacı satın alma arasında pozitif bir ilişki tespit edilememiştir. H6a, H6b ve H6c hipotezleri desteklenmemektedir.

Tablo 13.Regresyon Analizi (N:334)

\begin{tabular}{lll}
\hline & Bağımlı değişken: Faydacı satın alma & \\
\hline Bağımsız değişken & $\beta$ & $\mathbf{P}$ \\
\hline Sosyal &, 119 &, 137 \\
Çevresel &, 024 &, 710 \\
Kişisel &,- 052 &, 443 \\
\hline $\mathbf{R}$ &, 099 & \\
$\mathbf{R}^{2}$ &, 010 &, 000 \\
$\mathbf{F}$ & 1,087 & \\
\hline
\end{tabular}

"Faydacı satın alma ile ikinci el lüks motivasyon arasında pozitif bir ilişki bulunmaktadır" şeklinde düzenlenen H6d hipotezini incelemek için yapılan regresyon analizi ve test sonuçları Tablo $14^{\prime}$ te gösterilmiştir. Bu modelde bağımsız değişkenlere ikinci el lüks motivasyonu ilave edilmiştir. İkinci el lüks motivasyonu $(\beta=-0.22 ; p>0.05)$ ile faydacı satın alma arasında istatistiki olarak pozitif bir ilişki tespit edilmemiştir. H6d hipotezi desteklenmemektedir. 
D. Gezmişoğlu Şen - G. Telli 13/3 (2021) 2587-2606

Tablo 14.Regresyon Analizi (N:126)

\begin{tabular}{lll}
\hline & Bağımlı değişken: Faydacı satın alma & \\
\hline Bağımsız değişken & $\beta$ & $\mathbf{p}$ \\
\hline Lüks &,- 022 &, 799 \\
\hline $\mathbf{R}$ &, 023 & \\
$\mathbf{R}^{2}$ &, 001 &, 000 \\
$\mathbf{F}$ &, 065 & \\
\hline
\end{tabular}

\section{Sonuç ve Tartışma}

Son yıllarda tüketiciler arasında çevrimiçi alışveriş oldukça popülerleşmiştir. Çevrimiçi alışverişin bu kadar popüler olduğu ve tüketici davranışlarının bu denli değişimler gösterdiği bir ortamda çevrimiçi ikinci el pazarda istikrarlı bir şekilde büyümektedir. Bu büyüyen Pazar yeni fırsatları da beraberinde getirmekte olup tüketiciler arasında gitgide yaygınlaşan çevrimiçi ikinci el pazar alışverişi araştırmacıların da dikkatini çekmekte ve tüketici davranışlarının irdelenmesi önem kazanmaktadır.

$\mathrm{Bu}$ araştırmada, çevrimiçi ikinci el alışveriş yapan ve çevrimiçi alışveriş yapan tüketiciler incelenmiştir. Araştırmanın uygulama kısmında; demografik özelliklerin belirlenmesi için yöneltilen 17 soru yanında, toplam 7 farklı ölçek kullanılarak çevrimiçi anket çalışması düzenlenmiştir. Araştırma çevrimiçi ortamda kolayda örnekleme olarak gerçekleşmiştir. Anket 18 yaş üstü kadın ve erkeklerden oluşan 746 katılımcıya uygulanmış olup 57 anketin eksik/hatalı doldurulduğu fark edilmiştir. Böylelikle 689 adet kullanılabilir anket verisi incelenmiştir. Ankete katılan tüketicilerin çoğunluğu kadınlardan oluşmaktadır. Çevrimiçi alışverişe yönelik diğer araştırmalarda cinsiyet açısından herhangi bir farklılık bulunmamıştır (Witkowski ve Reddy, 2010; Steffen, 2016). Dolayısıyla kadınların çoğunlukta olmasının örneklemi etkilemediği sonucuna varılmıştır.

Tüketicilerin herhangi bir ürün ya da hizmeti aynı derecede önemsemediği, aynı yoğunlukta ilişki kurmadığı görülmektedir. (Koç, 2011). Bir ürünün her yerde bulunmaması durumu, tüketicileri araştırma ve bilgi toplamaya yönlendirmektedir. Tüketiciler bu durumdaki ürünlere ise yüksek ilgilenim göstermektedirler (Zanoli ve Naspetti, 2002). Yüksek ilgilenim düzeyine sahip müşterilerin, memnun olduklarında markaya veya firmaya yönelik sadakat duygusu geliştirdiklerini ve bu müşterilerin işletme açısından önemli bir pazar bölümü oluşturduğu bilinmektedir (Dölarslan, 2015; Warrington ve Shim, 2000). İkinci el çevrimiçi alışveriş yapan tüketicilerin ikinci el platformlardan satın aldıkları birtakım ürünlerin geleneksel pazarda olmamasından kaynaklı olarak ilgilenim düzeylerinde artış olması beklenmektedir. Bu bağlamda söz konusu tüketicilerin ürün ve pazar hakkında fazlaca bilgi sahip olduğu düşünülmektedir. Tüketicilerin bir ürüne yönelik olarak günden güne artan ilgilenimi sadece kişisel ilgiden ibaret değil aynı zamanda hedonik duygularla da ilişkilendirilmektedir. (Bloch ve Richins, 1983; Kapferer ve Laurent 1985). Tüketicinin ilgilenimi ile satın alma davranışı arasında pozitif bir ilişki olduğu da saptanmıştır (Choubtarash vd., 2013). Yapılan araştırmada ilgilenimin hedonik $(\beta=0.143, \mathrm{p}<0.01)$ satın alma ve kompulsif $(\beta=0.260, \mathrm{p}<0.01)$ satın alma tarz1 üzerinde pozitif bir ilişki olduğu görülmektedir. İlgilenimin, tüketicilerin satın alma davranışlarını arttırdığı düşünülürse kar elde etmek isteyen satıcıların tüketicilerin ilgilenimini arttırmaya yönelik çalışmalar yapması gerekmektedir. Ancak yapılan araştırmada ilgilenimin faydacı satın alma $(\beta=-0.019, p<0.05)$ tarzı üzerinde pozitif bir ilişkiye rastlanılmamıştır. Tüketicilerin artık satın alma kararlarında ürünlerin fonksiyonel faydası dışında farklı unsurlar aradıkları farklı davranışlar sergiledikleri bilinmektedir. Ancak ilgilenimi arttırmak adına faydacı satın alma tarzını benimseyen tüketicilere karşı ürünlerin fonksiyonel faydalarını göz ardı etmemek gerektiği düşülmektedir. Böylece faydacı satın alma yapan tüketicileri de ikinci el çevrimiçi platformlara çekmek mümkün olabilir.

Literatürde yenilikçiliği benimseyen tüketicilerin diğer tüketicilere göre çevrimiçi satın almaya karşı daha pozitif tutum sergiledikleri tespit edilmiştir (Goldsmith ve Foxall, 2003). Yenilikçilik arttıkça satın almanın da doğru orantılı bir şekilde arttığı bilinmektedir (Gielens ve Steenkamp, 2007). Yapılan araştırmada çevrimiçi tüketicilerin yenilikçiliğinin, hedonik satın alma $(\beta=0.313, p<0.01)$ tarzı ve kompulsif satın alma $(\beta=0.330$, $\mathrm{p}<0.01)$ tarzı arasında pozitif bir ilişki olduğu tespit edilmiştir. Yenilikçiliğin faydacı beklentilerle değil de hedonizmle pozitif bir ilişki içinde olduğu gözlemlenmiştir (Kim, 2010). Bu bağlamda çalışmada literatüre paralel olarak yenilikçilik ile faydacı satın alma $(\beta=-0.107, \mathrm{p}<0.05)$ arasında pozitif bir etkiye rastlanılmamıştır. 
Yine literatür ile benzer şekilde tüketici yenilikçiliğinin ürün ilgilenimini pozitif yönde etkilediği bulgusuna ulaşılmıştır (San-Martin ve Lo' pez-Catala'n, 2013; Bennett vd., 2005). İkinci el çevrimiçi pazarın çok yeni bir platform olduğu gözönüne alındığında yenilikçi tüketicilerin bu pazarı tercih etmesi olasıdır. Ayrıca çevrimiçi alışveriş yapan tüketicilerin hedonik ve kompulsif satın alma tarzını benimsediği bilinmektedir. Bu bağlamda yenilikçi tüketicilerin hedonik ve kompulsif satın alma tarzı ile ikinci el çevrimiçi platformlarda bulunduklarını söylemek mümkündür.

Çevrimiçi alışverişte algılanan fayda ve algılanan risk üzerine yapılan çalışmada elde edilen sonuca göre çevrimiçi alışveriş yapmanın, çevrimiçi ortamdaki belirsizliği ortadan kaldırdığı, çevrimiçi alışveriş yapmanın algılanan riski düşürdüğü sonucuna ulaşılmıştır (Durukan ve Karaoğlan, 2020; Forsythe ve Shi, 2003). Yapılan çalışmada da literatürle benzer olarak çevrimiçi tüketicilerde algılanan riskin kompulsif satın alma $(\beta=-0.182$, $\mathrm{p}<0.01)$ ve faydacı satın alma $(\beta=-0.89, \mathrm{p}<0.01)$ üzerinde pozitif bir ilişki olmadığı tespit edilmiştir. $B u$ araştırmada, diğerlerinden farklı olarakçevrimiçi tüketicilerin hedonik satın alma ile algılanan risk ( $\beta=0.129$, $\mathrm{p}<0.01)$ arasında pozitif bir ilişki tespit edilmiştir. Tüketicilerin satın alma kararlarını etkileyen en önemli tutumun algılanan risk olduğu düşünüldügünde, tüketicilerin güvenilirliğinden emin olduğu çevrimiçi platformlardan alışveriş yapma olasılıklarının yüksek olduğu bilinmektedir (Miyazaki ve Fernandez, 2001). Çevrimiçi alışverişin her geçen gün artmasına rağmen hala geleneksel alışverişe göre daha riskli olarak algılanmaktadır. Bu nedenle, çevrimiçi satış yapan satışçıların çevrimiçi alışveriş yapan tüketicilere karşı satın alma işlemini kolaylaştırması gerekmektedir (Laroche vd., 2005). Örneğin, ikinci el satış yapan sitelerdeki tüketicilerin, satış yapan satıcılara satış sonrası deneyimleri hakkında verdikleri yıldızlar (puanlar) yüksek ve tüketicilerin yaptıkları pozitif yorumlar satış yapanın bir sonraki alışverişini kolaylaştırmaktadır (Erdil, 2014). Bir diğer konuda satıcıların değişim ve iade güvencesi verilmesi, ikinci el lüks ürünler için ise ürünün geçmişine dair bilgi verilmesi de çevrimiçi tüketicilerin algılanan riskini azaltmaya yardımcı olacağ düşünülmektedir. Ayrıca, yeni müşterilere fikir vererek algılanan riskin azaltılmasına da katkı sağlamaktadır. Böylece tüketicinin alternatifleri seçme aşamasından kolaylıkla satın alma aşamasına geçmesine yardımcı olmaktadır.

Hedonik satın alma tarzı benimseyen tüketicilerin alışveriş yaparken hedonik boyutların ön planda olduğu kişiler arasında etkileşimlerin yaşandığı ve tüketicilerin bu etkileşimlerden dolayı ikinci el alışveriş sitelerini tercih ettikleri düşünülmektedir (Clausen vd., 2010). Alman tüketiciler üzerinde yapılan çalışmada da sosyal motivasyonun etkili olduğu sonucuna ulaşılmıştır (Steffen, 2016). Bu bağlamda elde edilen sonuçlar literatür ile doğru orantılı olarak yapılan çalışmada çevrimiçi ikinci el alışveriş yapan tüketicilerin sosyal motivasyonunun hedonik satın alma $(\beta=0.314, \mathrm{p}<0.01)$ ve kompulsif satın alma $(\beta=0.187, \mathrm{p}<0.01)$ tarzı arasında pozitif bir ilişki olduğu tespit edilmiştir. Hedonik ve kompulsif satın alma tarzını benimsemiş olan ikinci el çevrimiçi tüketicilerin diğer tüketicilerden, ailelerinden, yakınlarından, arkadaşlarından veya çevrimiçi platformlardan etkilendikleri düşünülmektedir.

Hedonik ve kompulsif satın alma tarzlarını benimseyen çevrimiçi tüketicilerin çevresel sebeplerin satın alma tarzlarını etkilemediği görülmektedir. Kompulsif tüketicilerin ekolojik kaygılardan uzak bir şekilde alışveriş alışkanlıklarına devam ettikleri görülmektedir. Hedonik tüketicilerin de çevre bilinci, döngüsel moda, sürdürülebilirlik gibi konulara eğilimleri olmasına rağmen çevrimiçi ikinci el alışveriş yaparken bu özellikleri göstermedikleri (Cervellon vd., 2012), çevresel sebepler yerine hazcı sebeplerden dolayı ikinci el alışveriş yaptıkları görülmektedir (Clausen vd., 2010) Ayrıca çevre bilinciyle hareket ederek ikinci el alışveriş yapan tüketicilerin de olduğunu söylemek gerekmektedir (Amatulli vd., 2018). Bu bağlamda literatür taraması sonucu elde edilen veriler ile yapılan araştırma verileri benzer özellikler göstermekte olup bu araştırmada çevrimiçi ikinci el alışverişte çevresel motivasyonun hedonik satın alma $(\beta=-0.190, p<0.01)$ ve kompulsif satın alma $(\beta=-0.237, \mathrm{p}<0.01)$ tarzı arasında pozitif bir ilişkiye rastlanılmamıştır.

Önceki çalışmalarda tüketicilerin satın alma işlemi gerçekleştirdiği lüks ürünlerde de sürdürülebilirliği destekleyici geri dönüştürülmüş malzemeler kullanılmasının tüketici tercihini olumsuz yönde etkilediği tespit edilmiştir (Achabou ve Dekhili; 2013). Tüketicilerin sosyal statülerini daha üst bir seviyeye çıkarmak amacıyla ikinci el lüks ürün satın alma eğiliminde oldukları düşünülmektedir (Kessous ve Florence, 2019). Bu bağlamda yapılan bu araştırmada ikinci el lüks ürün satın alan tüketicilerin hedonik satın alma $(\beta=0.301, p<0.01)$ ve kompulsif satın alma $(\beta=0.314, \mathrm{p}<0.05)$ tarzını pozitif yönde etkilediği tespit edilmiştir.

İngiltere'de ikinci el alışverişin ekonomik nedenlerle yapıldığı sonucuna ulaşılmıştır (Waight, 2013). Fakat 
İngiltere'de, yapılan çalışma yeni doğum yapan anneleri kapsadığından annelerin hem iş hayatına henüz geri dönmemiş olmaları hem de yeni bir bebeğin masraflarını göz önüne aldığında sonucun ekonomik nedenlerden çıkması hiç de şaşırtıcı değildir. Roux ve Guiot'un yaptıkları çalışmada Fransa'da büyük bir ekonomik krize denk gelmesinden kaynaklı olarak ekonomik motivasyonun yüksek çıtığı düşünülmektedir. Almanya'da yapılan çalışmada Alman tüketicilerin ekonomik olmayan nedenlerle alışveriş yaptıkları yani fiyattan etkilenmedikleri sonucuna ulaşılmıştır (Steffen, 2016). Bu bağlamda yapılan araştırmada çevrimiçi tüketicilerin ikinci el kişisel motivasyonu, hedonik satın alma $(\beta=-0.79, \mathrm{p}<0.01)$ ve kompulsif satın alma $(\beta=-$ 0.16, p <0.01) tarzı ile arasında pozitif bir etkiye rastlanılmamıştır. Çevrimiçi tüketicilerin fiyattan etkilenmedikleri, ekonomik nedenlerden dolayı ikinci el çevrimiçi alışveriş yapmadıkları farklı sebeplerden dolayı ikinci el çevrimiçi alışveriş yaptıkları sonucuna ulaşılmıştır.

$\mathrm{Bu}$ araştırmada ikinci el çevrimiçi satın alma motivasyonlarının (sosyal, çevresel, kişisel, lüks) faydacı satın alma üzerinde pozitif bir etkisi olmadığı görülmektedir. Faydacı satın alma eğiliminde olan tüketicilerin ise en uygun ve işlevsel ürünleri tercih ettikleri bilinmektedir. Bu sebeple, ikinci el çevrimiçi lüks ürün alışverişi yapan tüketicilerin faydacı satın alma ile alışveriş yapmadıkları görülmektedir. İkinci el çevrimiçi satış yapan satışçıların, ürünlerin fonksiyonel faydalarını ön plana çıkararak faydacı satın alan tüketicileri de ikinci el satın almaya teşvik etmesi sağlanarak ikinci el çevrimiçi platformlara katılımın arttırılabileceği düşünülmektedir.

Tüketici tutumlarının satın alma niyeti üzerinde önemli bir belirleyici etken olduğu bilinmektedir (Fishbein ve Ajzen, 1975; Peña-García vd., 2020). İkinci el satın alma niyetinin incelendiği çalışmada tüketicilerin tutumunun tüketicilerin satın alma niyetini etkilediği görülmektedir (Telli, Aydın ve Gezmişoğlu Şen ,2021). $\mathrm{Bu}$ araştırmada kompulsif $(\beta-0.61, \mathrm{p}<0.01)$, hedonik $(\beta-0.34, \mathrm{p}<0.01)$ ve faydacı $(\beta, 088, \mathrm{p}>0.05)$ satın alma tarzları ile ikinci el çevrimiçi satın alma niyeti arasında pozitif herhangi bir ilişki tespit edilememiştir. Çevrimiçi satış yapan satıcılar, tüketici tutumlarında pozitif değişimlerin oluşmasını sağlayabilecek stratejiler geliştirirlerse, tüketicilerin satın alma niyetlerinde de pozitif değişimlerin meydana gelmesi olasıdır. Bu sonuçtan hareketle çevrimiçi ikinci el satış yapanların çevrimiçi tüketicilerin hazcı duygularını ortaya çıkaracak stratejiler, faydacı satın alma işlemi yapan çevrimiçi tüketicilerin istek ve ihtiyaçlarına uygun stratejiler ve kompulsif satın alma eğiliminde olan çevrimiçi tüketicilere uygun stratejiler geliştirerek ikinci el satın almaya yönlendirilerek ikinci el platformlara daha fazla katılım sağlanabilir.

Sonuç olarak ikinci el çevrimiçi alışveriş motivasyonlarının belirlenmesini inceleyen hem ulusal hem de uluslararası araştırma sayısının sınırlı olduğunu söylemek mümkündür. Literatürde yapılan araştırmalarda ikinci el satın alma motivasyonlarını; ilgilenim, yenilikçilik, algılanan risk, satın alma niyeti ve satın alma tarzları (hedonik, kompulsif ve faydacı) değişkenleri ile ilişkisini birlikte ele alan bir araştırmaya rastlanmadığı göz önüne alınırsa, ulaşılan bu bulguların literatür için önemli bir katkı sağladığı düşünülebilir.

Gelecek araştırmalarda daha fazla çevrimiçi ikinci el alışveriş sitesi ve farklı ürünler üzerinden (örneğin beyaz eşya, otomobil, tekstil gibi) göz önüne alınarak çalışmalar yapılabilir. Seçilen farklı ikinci el çevrimiçi alışveriş siteleri özellikleri ve tüketici etkileşimi, tüketici yaklaşımlarına bakılabilir. Daha sonraki araştırmalarda evren ve örneklem bakımından daha geniş bir zaman ve daha fazla maliyet harcanarak yapılan araştırmalarda farklı sonuçlar elde etmek de mümkündür.

$\mathrm{Bu}$ araştırmada Türkiye'de ikinci el çevrimiçi tüketiciler açısından ikinci el satın alma motivasyonları incelenmiştir. Gelecekteki araştırmalarda çevrimiçi ikinci el satış yapan satıcılar açısından değerlendirmeler ve/veya ikinci el motivasyonları harekete geçirecek eylemler konusunda ya da farklı ülkelerde yer alan ikinci el çevrimiçi pazarlara ilişkin karşılaştırmalı araştırmalar ve analizler yapılabilir. 


\section{Kaynakça}

Abbes, İ., Hallem, Y., and Taga, N. (2020). Second-hand shopping and brand loyalty: The role of online collaborative redistribution platforms. Journal of Retailing and consumer Services ,52,101885

Achabou, M. A., and Dekhili, S. (2013). Luxury and sustainable development: Is there a match? Journal of Business Research, 66 (10), 1896-1903.

Arnold, M. J., and Reynolds, K. E. (2003). Hedonic Shopping Motivations. Journal of Retailing, 79 (2), 77-95.

Babin, B. J., Darden, W. R., \& Griffin, M. (1994). Work and or Fun: Measuring Hedonic and Utilitarian Shopping Value. Journal of Consumer Research, 20 (4), 644-656.

Balabanis, G., Mueller, R., and Melewar, T. C. (2002). The Relationship Between Consumer Shopping Ethnocentrism and Human Values. Journal of Global Marketing, 15 (3-4), 7-37.

Bauer, R. A. (1960). Consumer Behavior as Risk Taking. R. S. Hancock (Dü.), In Dynamic Marketing for A Changing Worm içinde (s. 389-398). Chicago: American Markting Association.

Bennett, R. R., Hartel, C., and McColl-Kennedy, J. R. (2005). Experience as a moderator of involvement and satisfaction on brand loyalty in a business-to-business setting 02-314R. Industrial Marketing Management , 34 (1), 97-107.

Boston Consulting Group. (2019). 2019 True-Luxury Global Consumer Insight. Milano: AltaGamma.

Chen, K., Luo, P., and Wang, h. (2017). An Influence Framework on Product Word-of-Mouth (WoM). Information \& Management, 54, 228-240.

Clausen, J., Birgit, B.-M., Erdmann, L., and Henseling, C. (2010). Contribution of Online Trading of Used Goods to Resource Efficiency: An Empirical Study of eBay Users. Sustainabiility, 2 (6),1810-1830

Crowley, A. E., Spangenberg, E. R., and Hughes, K. R. (1992). Measuring the hedonic and utilitarian dimensions of attitudes toward product categories. Marketing Lestters, 3 (3), 239-249.

Davis, F. D. (1989). Perceived usefulness, perceived ease of use, and user acceptance of information technology. MIS Quarterly,13, 318-339.

Dittmar, H. (2005). Compulsive buying - A growing concern? An examination of gender, age, and endorsement of materialistic values as predictors. British Journal of Psychology, 96 (4), 467-691.

Dölarslan, E. Ş. (2015). Tüketicilerin Ürün İlgilenimi ve Bilgi Düzeyini Marka Sadakatine Etkisinin Fikir Liderliği Kapsamında Değerlendirilmesi. Pazarlama ve Pazarlama Araştırmaları Dergisi (15), 24-48.

Fernando, A. G., Sivakumaran, B., and Suganthi, L. (2018). Comparison Of Perceived Acquisition Value Sought By Online Second-Hand And New Goods Shoppers. European Journal of Marketing, 52 (7/8),14131437.

Ferraro, C., Sands, S., and Brace Govan, J. (2016, Eylül). The role of fashionability in second-hand shopping motivations. Journal of Retailing and Consumer Services ,32, 262-268.

Flynn, L. R., and Goldsmith, R. E. (1993). A Validation of the Goldsmith and Hofacker Innovativeness Scale. educational and Psychological Measurement, 53 (4), 1105-1116.

Fishbein, M., and Ajzen, I. (1975). Belief, Attitude, Intention, and Behavior: An Introduction to Theory and Research. Reading, MA: Addison-Wesley

Foxall, G. R., \& Bhate, S. (1993). Cognitive Style and Personal Involvement as Explicators of Innovative Purchasing of "Healthy" Food Brands. European Journal of Marketing, 27 (2), 5-16.

Forsythe, S. and Shi, B. (200 3). Consumer patronage and riblossk perceptions in Internet shopping, Journal of Business Research, 56, 867-875.

Garcia, R., and Kandemir, D. (2006). An illustration of modeling moderating variables in cross-national studies. International Marketing Review, 23 (4), 371-389.

George, D., and Mallery, P. (2010). SPSS for Windows step by step : a simple guide and reference, 17.0 update. Boston: Allyn\&Bacon.

Gielens, K., and Steenkamp, J.-B. (2007). Drivers of consumer acceptance of new packaged goods: An investigation across products and countries. International Journal of Research in Marketing ,24(2), 97-111. 


\section{Gezmişoğlu Şen - G. Telli 13/3 (2021) 2587-2606}

Goldsmith, R. E., and Foxall, G. R. (2003). the International Handbook on Innovation. (S. V. Larisa, Dü.) Elsevier Science.

Goldsmith, R. E., and Hofacker, C. (1991). Measuring Consumer Innovativeness. Journal of the Academy of Marketing Science, 19(3),209-221.

Guiot, D., and Roux, D. (2010). A Second-hand Shoppers' Motivation Scale: Antecedents, Consequences, and Implications for Retailers. Journal of Retailing , 86(4), 355-371.

Guo, Z., and Cai, Y. (2011). xploring the antecedents of compulsive buying tendency among adolescents in China and Thailand: A consumer socialization perspective. African Journal of Business Management, 5 (24),10198-10209.

Hem, L. E., L., D. C., and Iversen, N. M. (2001). Journal of Marketing Management. Factors Influencing Successful Brand Extensions, 19 (7-8), 781-806.

Herr, P., Kardes, F. R., and Kim, J. (1991). Effects of Word-of-Mouth and Product-Attribute Information on Persuasion: An Accessibility-Diagnosticity Perspective. Journal of Consumer Research, 17 (4), 454-462.

Hirunyawipada, T., and Paswan, A. K. (2006). Consumer Innovativeness and Perceived Risk: Implications for High Technology Product Adoption. Journal of Consumer Marketing, 23 (4), 182-189.

İyzico, (2019).www.iyzico.com. (2019, 03 21).ekim 2020 tarihinde alındı

James, R. (2019, 01 22). Rise of the Fashion Resale Marketplaces. Florida, ABD: The Raymond James Financial Center.

Joung, H.-M., and Park-Poaps, H. (2013). Factors motivating and influencing clothing disposal behaviors. International IJC, 37 (1),105-111.

Karaoğlan, S., Durukan., T. (2020). Dijital Pazarlama Çağında Çevrimiçi Alışverişin Fayda ve Risk Alg1sı,İşletme Araştırmaları Dergisi, 12 (2), 1072-1082.

Kavak, B., and Sığındı, T. (2012). Pazarlama'daki Ürün Sınıflandırmasına İlişkin Bir Yazın İncelemesi. H.Ü. İktisadi ve İdari Bilimler Fakültesi Dergisi, 30 (1), 49-67.

Kessous, A., and Valette-Florence, P. (2019). From Prada to Nada": Consumers and their luxury products: A contrast. Journal of Business Research, 102 (C),313-327.

Kim, L., Woo, H., and Ramkumar, B. (2021). The role of product history in consumer response to online secondhand clothing retail service based on circular fashion. Journal of Retailing and Consumer Services,60, 102457.

Klink, R. R., and Smith, D. C. (2001). Threats to the External Validity of Brand Extension Research. Journal of Marketing Research, 38 (3),326-335.

Kotler, P., Kartajaya, H., and Setiawan, I. (2018). Pazarlama 4.0 Gelenekselden Dijitale Geçiş. (N. Özata, Çev.) İstanbul: Optimist Kitap.

Kukar-Kinney, M., Ridgway, N. M., and Monroe, K. B. (2009). The Relationship Between Consumers' Tendencies to Buy Compulsively and Their Motivations to Shop and Buy on the Internet. Journal of Retailing, 85 (3), 298-307.

Kukar-Kinney, M., Scheinbaum, A. C., and Schaefers, T. (2016). Compulsive Buying in Online Daily Deal Settings: An Investigation of Motivations and Contextual Elements. Journal of Business Research, 69, 691699.

Kutlu, D., ve Ayyıldız, H. (2017). Konaklama İşletmelerinde Elektronik Ağıdan Ağıza İletişimin Tüketici Ve Oteller Açısından Değerlendirilmesi. Turzim ve Araştırma Dergisi, 1 (6), 40-58.

Laroche, M., Yang, Z., McDougall, G. H., and Bergeron, J. (2005). Internet versus bricks-and-mortar retailers: An investigation into intangibility and its consequences. Journal of Retailing, 81 (4), 251-267.

Laurent, G., and Kapferer, J. N. (1993). Further Evidence on the Consumer Involvement Profile: Five Antecedents of Involvement. Psychology and Marketing, 10 (4),347-355.

Lee, M. K., Cheung, C. M., and Thadani, D. R. (2009). The Impact of Positive Electronic Word-of-Mouth on Consumer Online Purchasing Decision. Visioning and Engineering The Knowledge Society A Web Science Perspective (s. 501-510). In Computer Science. 


\section{Gezmişoğlu Şen - G. Telli 13/3 (2021) 2587-2606}

Lee, M., Rodgers, S., and Kim, M. (2009). Effects of Valence And Extremity of Ewom on Attitude Toward The Brand and Website. Journal of Current Issues and Research in Advertising, 31 (2), 1-11.

Midgley, D. F., and Dowling, G. (1978). Innovativeness: The Concept and Its Measurement. Journal of Consumer Research, 4 (4), 229-242.

Mittal, B. (1995). A comparative analysis of four scales of consumer involvement. Psychology \& Marketing, 12 (7), 663-682.

Miyazaki, A. D., and Fernandez, A. (2001). Consumer Perceptions of Privacy and Security Risks for Online Shopping. Journal of Consumer Affairs, 35 (1), 27-44.

Moon, M. A., Khalid, M. J., Awan, h. M., Attiq, S., Rasool, H., and Kiran, M. (2017). Consumer's perceptions of website's utilitarian and hedonic attributes and online purchase intentions: A cognitive-affective attitude approach. Spanish Journal of Marketing ,21(2), 73-88.

Nakip, M. (2013). Pazarlamada araştırma teknikleri ve SPSS uygulamaları. Ankara: Seçkin Yayıncılık.

O'Cass, A. (2000). $\mathrm{n}$ assessment of consumers product, purchase decision, advertising and consumption involvement in fashion clothing. ournal of Economic Psychology, 21 (5), 545-576.

Olsen, S. O. (2007). Repurchase Loyalty:The Role of Involvement and Satisfaction. Psychology \& Marketing, $24(4), 315-341$.

O'Shaughnessy, J., and O'Shaughnessy, N. (2002). Marketing, The Consumer Society And Hedonism. European Journal of Marketing (36), 524-547.

Padmavathy, C., Swapana, M., and Paul, J. (2019). Online second-hand shopping motivation Conceptualization, scale development, and validation. Journal of Retailing and Consumer Services, 51(C),19-32.

Park, C., Wang, Y., Yao, Y., and Kang, Y. R. (2011). Factors Influencing eWOM Effects: Using Experience,Credibility, and Susceptibility. International Journal of Social Science And Humanity, 1 (1),7479.

Park, H. J., and Burns, L. D. (2005). Fashion Orientation, Credit Card Use, and Compulsive Buying. Journal of Consumer Marketing, 22 (3), 135-141.

Peña-García, N., Gil-Saura, I., Rodríguez-Orejuela, A., and Siqueira-Junior, J. R. (2020). Purchase intention and purchase behavior online: A crosscultural approach. Heliyon, 6(6), e04284.

Ridgway, N. M., and Kukar-Kinney, M. (2012). The Role of Price in the Behavior and Purchase Decisions of Compulsive Buyers. Journal of Retailing, 88 (1), 1-10.

Richins, M.L. and Bloch, P.H. (1986). After the New Wears off: The Temporal Context of Product Involvement. Journal of Consumer Research. 13 (2): 280-285.

Roberts, J. A., and Jones, E. (2005). Money Attitudes, Credit Card Use, and Compulsive Buying among American College Students. Journal of Consumer Affairs, 35 (2), 213-240.

San-Martin, S., and Lopez-Catalan, B. (2013). How can a mobile vendor get satisfied customers? Industrial Management \& Data Systems , 113 (2), 156-170.

Şen Ö. (2019). Online alışverişte algılanan risk faktörlerinin alışverişe yönelik tutuma etkisinin incelenmesi, International Journal of Scientific and Technological Research, 5(8), 11-24.

Shahbandeh, M. (2021, 01 11). www.statista.com. 04 23, 2021 tarihinde statista. adresinden alındı

Shoham, A., and Brencic, M. M. (2003). Compulsive Buying Behavior. The Journal of Consumer Marketing, 20 (2), 127-138.

Shuling, L., Chu Is, H., and Chu, H. (2007). Exploring consumer resale behavior in C2C online auctions: Taxonomy and influences on consumer decisions. Academy of Marketing Science Review, 11 (3),1-16.

Sneath, J. Z., Lacey, R., and Kennett-Hansel, P. A. (2009). Coping with a natural disaster: Losses, emotions, and impulsive and compulsive buying. Marketing Letters, 20 (1), 45-60.

Statista, (2019a). https://www.statista.com/statistics/691842/usa-c2c-second-ecommerce -platforms/. (Erişim tarihi: 25/04/2021). 


\section{Gezmişoğlu Şen - G. Telli 13/3 (2021) 2587-2606}

Statista, (2016a). https://www.statista.com/statistics/695035/online-and-offline-second-hand-economy-initaly/.(Erişim tarihi: 25/04/2021).

Statista, (2020a). https://www.statista.com/statistics/1223891/south-korea-second-hand-shopping-app-usage/. (Erişim tarihi: 25/04/2021).

Statista, (2020b). https://www.statista.com/statistics/1139105/china-annual-gmv-growth -of-second-hand-ecommerce/.(Erişim tarihi: 25/04/2021). Steffen, A. (2016). Second-hand consumption as a lifestyle choice. 190-207.

Stone, R. N., and Gronhaug, K. (1993). Perceived Risk: Further Considerations for the Marketing Discipline. European Journal of Marketing,, 27 (3), 39-50.

Stone, R. N., \& Mason, B. J. (1995). Attitude and Risk: Exploring the Relationship. Psychology\&Marketing , 12 (2), 135-152.

Suki, N., and Suki, N. M. (2007). Online buying innovativeness: effects of perceived value, perceived risk and perceived enjoyment. International Journal of Business and Society,8(2),81-93.

Telli, G., Aydın, S., ve Gezmişoğlu Şen, D. (2021). COVID-19 Sürecinde Çevrimiçi İkinci El Ürün AlışverişineYönelik Tutum ve Satın Alma Niyeti Üzerine Bir Araştırma. Journal of Aksaray University Faculty of Economics and Administrative Sciences , 13 (2), 11-22.

Trusov, M., and Decker, R. (2010). Estimating Aggregate Consumer Preferences from. Internstional Journal of Research in Marketing, 27, 293-307.

Turunen, L. L., Cervellon, M.-C., and Carey, L. D. (2019, Aralık). Selling Second-hand Luxury: Empowerment and Enactment of Social Roles. Journal of Business Research,116,474-481.

Türk Dil Kurumu. (2020). http://www.tdk.gov.tr/. 112020 tarihinde Türk Dil Kurumu.

Türkiye İstatistik Kurumu. (2020, 08 25). www.tuik.gov.tr. 11 8, 2020 tarihinde Türkiye İstatistik Kurumu:https://data.tuik.gov.tr/Bulten/Index?p=Hanehalki-Bilisim-Teknolojileri-(BT)-KullanimArastirmasi-2020-33679 adresinden alınd1

Tüsiad. (2018). https://www.eticaretraporu.org/wp-content/uploads/2019/05/DD-TUSIAD-ETicaret-Raporu2019.pdf. 11 5, 2019 tarihinde https://tusiad.org/tr/.

Verbeke, W., \& Vackier, I. (2003). Profile And Effects of Consumer Involvement in Fresh Meat. Meat Science, 67(1), 159-168.

Vijayasarathy, L. R. (2004). Predicting consumer intentions to use on-line shopping:the case for an augmented technology acceptance model. Information \& Management (41), 747-762.

Völckner, F., and Sattler, H. (2006). Drivers of Brand Extension Success. Journal of Marketing, 70 (2), 18-34.

Warrington, P., and Shim, S. (2000). An empirical investigation of the relationship between product involvement and brand commitment. Psychology \& Marketing, 17: 761-782.

Williams, C. C., \& Paddock, C. (2003). The meanings of informal and second-hand retail channels: Some evidence from Leicester. The International Review of Retail Distribution and Consumer Research Distribution and Consumer Research(3 , 317-336.

Witkowski, T. H., and Reddy, S. (2010). Antecedents of ethical consumption activities in Germany and the United States. Australasian Marketing Journal , 18 (1), 8-14.

Zaichkowsky, J. (1985). Measuring the Involvement Construct. Journal of Consumer Research , 12 (3), 341-352.

Zanoli, R., and Naspetti, S. (2002). Consumer motivations in the purchase of organic food: A means-end approach. British Food Journal , 104 (8), 643-653. 